\title{
Submarine landslides in the Santa Barbara Channel as potential tsunami sources
}

\author{
H. G. Greene ${ }^{1}$, L. Y. Murai ${ }^{2}$, P. Watts ${ }^{3}$, N. A. Maher ${ }^{4}$, M. A. Fisher ${ }^{5}$, C. E. Paull ${ }^{1}$, and P. Eichhubl ${ }^{6}$ \\ ${ }^{1}$ Monterey Bay Aquarium Research Institute (MBARI), 7700 Sandholdt Road, Moss Landing, CA 95039; Moss Landing \\ Marine Laboratories, 8272 Moss Landing Road Moss Landing, CA 95039, USA \\ ${ }^{2}$ Moss Landing Marine Laboratories, 8272 Moss Landing Road, Moss Landing, CA 95039, USA \\ ${ }^{3}$ Applied Fluids Engineering, Inc., 5710 E. 7th Street, PMB \#237, Long Beach, CA 90803, USA \\ ${ }^{4}$ AOA Geophysics, Inc., 7532 Sandholdt Road, Moss Landing, CA 95039, USA \\ ${ }^{5}$ United States Geological Survey, MS 999, 345 Middlefield Road, Menlo Park, CA 94025, USA \\ ${ }^{6}$ Stanford University, Department of Geological and Environmental Sciences, Stanford, CA 94305, USA
}

Received: 13 June 2005 - Revised: 26 October 2005 - Accepted: 15 November 2005 - Published: 16 January 2006

Part of Special Issue "Tsunami hazard from slope instability"

\begin{abstract}
Recent investigations using the Monterey Bay Aquarium Research Institutes (MBARI) Remotely Operated Vehicles (ROVs) "Ventana" and "Tiburon" and interpretation of MBARI's EM $30030 \mathrm{kHz}$ multibeam bathymetric data show that the northern flank of the Santa Barbara Basin has experienced massive slope failures. Of particular concern is the large $\left(130 \mathrm{~km}^{2}\right)$ Goleta landslide complex located off Coal Oil Point near the town of Goleta, that measures $14.6-\mathrm{km}$ long extending from a depth of $90 \mathrm{~m}$ to nearly $574 \mathrm{~m}$ deep and is $10.5 \mathrm{~km}$ wide. We estimate that approximately $1.75 \mathrm{~km}^{3}$ has been displaced by this slide during the Holocene. This feature is a complex compound submarine landslide that contains both surfical slump blocks and mud flows in three distinct segments. Each segment is composed of a distinct head scarp, down-dropped head block and a slide debris lobe. The debris lobes exhibit hummocky topography in the central areas that appear to result from compression during down slope movement. The toes of the western and eastern lobes are well defined in the multibeam image, whereas the toe of the central lobe is less distinct. Continuous seismic reflection profiles show that many buried slide debris lobes exist and comparison of the deformed reflectors with ODP Drill Site 149, Hole 893 suggest that at least 200000 years of failure have occurred in the area (Fisher et al., 2005a). Based on our interpretation of the multibeam bathymetry and seismic reflection profiles we modeled the potential tsunami that may have been produced from one of the three surfical lobes of the Goleta slide. This model shows that a $10 \mathrm{~m}$ high wave could have run ashore along the cliffs of the Goleta shoreline.
\end{abstract}

Correspondence to: $\mathrm{H}$. G. Greene

(greene@mbari.org)
Several other smaller $\left(2 \mathrm{~km}^{2}\right.$ and $\left.4 \mathrm{~km}^{2}\right)$ slides are located on the northern flank of the Santa Barbara Basin, both to the west and east of Goleta slide and on the Conception fan along the western flank of the basin. One slide, named the Gaviota slide, is $3.8 \mathrm{~km}^{2}, 2.6 \mathrm{~km}$ long and $1.7 \mathrm{~km}$ wide. A distinct narrow scar extends from near the eastern head wall of this slide for over $2 \mathrm{~km}$ eastward toward the Goleta slide and may represent either an incipient failure or a remnant of a previous failure. Push cores collected within the main head scar of this slide consisted of hydrogen sulfide bearing mud, possibly suggesting active fluid seepage and a vibra-core penetrated $\sim 50 \mathrm{~cm}$ of recent sediment overlying colluvium or landslide debris confirming the age of $\sim 300$ years as proposed by Lee et al. (2004). However, no seeps or indications of recent movement were observed during our ROV investigation within this narrow head scar indicating that seafloor in the scar is draped with mud.

\section{Introduction}

The concept of submarine landslides as major sources of tsunamis has recently reached a new high. This present concern is based on the disastrous July 1998 tsunami in Papua New Guinea that completely destroyed the villages around Sissano Lagoon and killed over 2200 people. Based on extensive offshore investigations after the event, the tsunami probably was produced by a large submarine landslide located offshore from the village and triggered in part by a widely felt M7 earthquake (Tappen et al., 1999, 2001; Synolakis et al., 2002; Davies et al., 2003). Within about $10 \mathrm{~min}$ of the offshore failure and around $30 \mathrm{~min}$ after the main shock, a wave some $10 \mathrm{~m}$ high inundated the low-lying spit and 


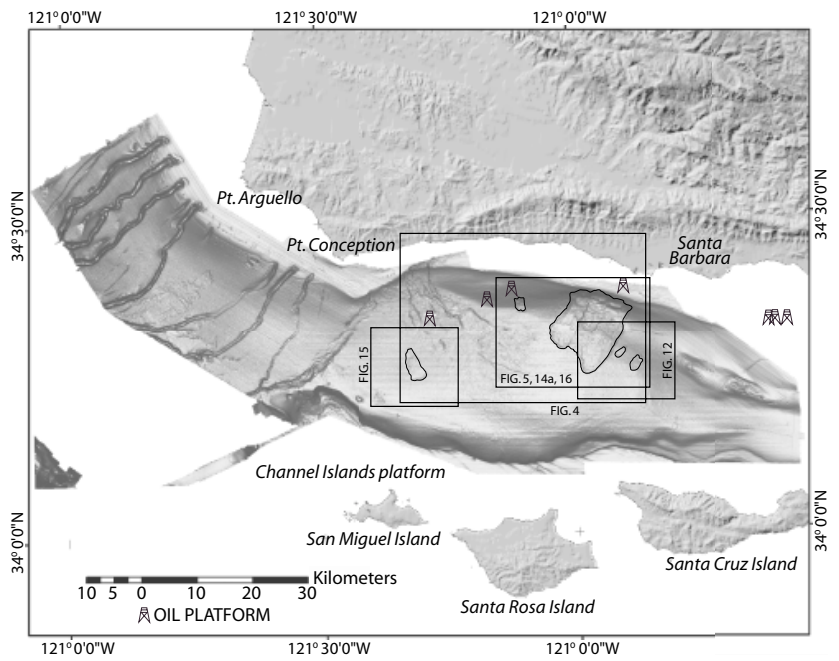

Fig. 1. Computer generated artificial sun-shaded relief image of the Santa Barbara Channel from Simrad EM300 $30 \mathrm{kHz}$ multibeam bathymetric data showing area of study, oil platforms, and principal geographic locations. Cross-like symbols represent oil platforms. Boxes show location of other figures.

lagoon along which the villages were located and stimulated a world wide call for the study of such phenomenon so that future calamities can be prevented, or at least predicted and mitigated. This call has again been renewed after the "Boxing Day" 26 December 2004 Sumatra M9+ earthquake that produced the Indian Ocean tsunami that left nearly 275000 people dead or missing and more than a million others homeless.

It has long been known that submarine failures within restricted bodies of waters such as bays and fiords regularly occur forming distinct seafloor scars (Shepard, 1933; Hampton et al., 1993; Prior et al., 1978, 1982; Plafker et al., 1969). Delta fronts exhibit slide scars produced from low angle failures of weak, fine-grained sediment (Prior et al., 1981). Failures on volcanic island flanks (Moore et al., 1989, 1994; Silver et al., 2005) and along the upper continental slope (Field and Edwards, 1980; Schwab et al., 1993; Lee et al., 1993, 2003; Field et al., 1999; Hampton and Bouma, 1977; Hampton et al., 1996) are also well known. All of these types of failures have produced local tsunamis in the past, some with large run-up that extensively damaged population centers (i.e., in Alaska, the Turnagain Arm, Seward, and Valdez failures of 1964; Plafker et al., 1969; Wilson and Torum, 1972; Hampton et al., 1993) and others that could have caused major damage if the areas were occupied at the time of the event. Many of these landslide sites have been mapped in the past using seismic reflection profiling techniques and extensively sampled for geotechnical properties using corers. Through these studies initial criteria for the local generation of a tsunamis by a mass movement event have been established (Ward, 2001; Greene and Ward, 2003). In order to produce a tsunami of significant size (2-10 m height at the shoreline) that would have substantial (10-20 m) local run-up elevation, a seafloor failure needs to be in intermediate to shallow water depths, be generally no deeper than $1000 \mathrm{~m}$, be of significant volume (i.e., greater than $2 \mathrm{~km}^{3}$ ), consist of stiff cohesive materials such as firm clay, and accelerate rapidly (Watts et al., 2000, Ward, 2001; Greene and Ward, 2003). Rules of thumb for landslide tsunami amplitudes are hard to come by because there are many different length scales that impact tsunami amplitude (Watts, 2004c).

Although much work, as noted above, has been done on specific submarine landslides to determine their history and cause of failure, much more work is needed to determine how a failure disintegrates and what the potential is for future mass movements. New technology, such as high-resolution digital multibeam bathymetric and backscatter mapping systems, have produced images of many of the previously studied landslides and have detected many others. These images exhibit such high-resolution (on the order of meters) features that the texture and detailed morphology of a slide surface can be resolved. In addition, modern observational and sampling capabilities provided with remotely operated vehicles (ROVs) allow for specific and selective sampling. We used such technologies to study the northern flank of the Santa Barbara Basin, an area of extensive mass wasting (Fig. 1).

While tsunamigenic landslides are generally thought to be triggered through seismic loading, many tsunamis can be generated from non-seismic related submarine failures. Other mechanisms that can stimulate mass movement on the seafloor include loading of slope sediment by storm waves or hurricanes, elevated sediment pore pressures from dewatering in response to tectonic compression or rapid increase of overburden pressures, reduction of stress by bubble phase gas expansive pressures, artesian pressures, seepage forces, gas hydrate disassociation, and sediment accumulations exceeding the angle-of-repose. If these non-seismogenic failures are large enough and accelerate rapidly enough, a tsunami can be produced. However, along active plate margins, such as in the Santa Barbara Basin region, seismicity can play a major role in generating tsunamigenic landslides.

The objectives of this study are to describe mass wasting along the northern flank of the Santa Barbara Basin using recently acquired multibeam data, seismic reflection profiles, ROV observations and seafloor samples collected by ROVs, to determine the causes for mass wasting and to assess the potential for future seafloor failures. In addition, we evaluate the geologic evidence for the cause of the 1812 tsunamis and selectively model a tsunami that may have originated from previous mass movement events.

\subsection{Previous work}

Seafloor failures along the northern flank of the Santa Barbara Channel were first described by Duncan et al. (1971). Later mapping and geohazards investigations in response to concerns about drilling for oil in the Santa Barbara Channel and of mass movement were reported in a series of reports including the United States Geological Survey (1975) and Crissman and Ploessel (1979). Ploessel et al. (1979), 
Thornton and Crissman (1979), Richmond (1981), Burdick and Richmond (1982) summarized hazards and engineering constraints for oil and gas development decisions while Edwards et al. $(1982,1993)$ presented seismic reflection profile data as evidence of slope failures in the Santa Barbara Channel. Thornton $(1984,1986)$ used sediment data to show why landslides in the channel are spatially distributed. Vedder et al. (1986) and McCulloch et al. (1989) mapped landslides in the central California region at a scale of 1:250000 using seismic reflection profiles. Eichhubl et al. (2002) used EM $300(30 \mathrm{kHz})$ bathymetric images to map mass movement features in the region. The largest and most conspicuous slope failure on the northern Santa Barbara Basin flank, the Goleta slide located south of Coal Oil Point, was initially mapped by Richmond et al. (1981) and later reported upon by Burdick and Richmond (1982) and Vedder et al. (1986, 1989). Another well-described submarine landslide is the Gaviota mudflow of Edwards et al. (1995) and Hampton et al. (1996) that was first described as flow $\mathrm{H}$ by Thornton $(1984,1986)$ and is located approximately $8 \mathrm{~km}$ west of the Goleta slide. Several other mass movement features generally located along the lower slope extending westward from west of Ventura around the northern flank of the Santa Barbara Basin to the central part of the southern slope have been described as slides A through I by Thornton (1984).

\section{Active tectonic setting}

The Santa Barbara Basin is part of the Southern California Borderland Province and generally is a canyonless, transform margin basin (Fig. 1). It is the most northerly basin of a series of basins, and unlike the other basins to the south, it is oriented east-west rather than northwest-southeast, the result of north-south compression. The basin has a maximum water depth of $589 \mathrm{~m}$ with $96 \%$ of the $2300 \mathrm{~km}^{2}$ area deeper than the shelf break comprised of slope (Thornton, 1984). The basin formed about $15 \mathrm{Ma}$ by lateral shear along the Pacific-North American transform plate boundary (Crowell, 1974; Howell, 1976). It is a foreland basin of the southward propagating deformation front of the Santa Ynez Mountains (Yeats, 1981; Namson and Davis, 1988). Today active deformation and uplift is documented by the dating of marine terraces and repeated precision leveling. For example, based on the dating of exhumed marine terraces the growth rate of the Ventura Avenue anticline, located north of Ventura, was found to be rising at a rate as high as $9 \mathrm{~mm} / \mathrm{yr}$ (Lajoie et al., 1991; Rockwell et al., 1988; Fig. 2a) during the Pleistocene and $2 \mathrm{~mm} / \mathrm{yr}$ today based on repeated precision leveling (Sylvester, 2000). The basin itself is being actively shortened by compression as shortening rates across the basin measured by geodetic observations using very-long-baseline interferometry and global positioning systems range from 5$8 \mathrm{~mm} / \mathrm{yr}$ east of Ventura to approximately $2 \mathrm{~mm} / \mathrm{yr}$ in the western part of the basin (Feigl et al., 1993; Larsen et al., 1993). Post-Miocene shortening also decreases from up to
$34 \%$ near Ventura to $2 \%$ in the southern and western part of the basin (Sorlien et al., 2000).

The basin is flanked on the south by the Channel Islands comprised of Anacapa, Santa Cruz, Santa Rosa and San Miguel islands, the offshore extension of the Santa Monica Mountains to the east, and on the north by the Santa Ynez Mountains (Fig. 2a). The basin floor is generally flat, less than $0.4^{\circ}$ slope, and has a maximum depth of $589 \mathrm{~m}$ with two sills, one, the Conception sill, at $470 \mathrm{~m}$ on the west and the other, the Hueneme sill, at $250 \mathrm{~m}$ on the east that separate the basin from the Pacific Ocean seafloor and restricts bottom circulation. The steepest slopes of the basin are located along the northern and southern flanks. An average slope of $2.5^{\circ}$ is found on the northern flank and $1.7^{\circ}$ on the southern flank. Locally the steepest slope is located below the edge of the San Miguel Island shelf at $20^{\circ}$. The island shelf is the top of the Channel Island platform and ranges from 5 to $10 \mathrm{~km}$ wide with the shelf edge generally located at the $100 \mathrm{~m}$ isobath. The mainland, or northern, shelf is variable in width ranging from over $15 \mathrm{~km}$ in the east with the shelf break at the $100 \mathrm{~m}$ isobath to $4.5 \mathrm{~km}$ offshore of Gaviota with a shelf break ranging from $85 \mathrm{~m}$ deep south of Santa Barbara to $50 \mathrm{~m}$ deep near Gaviota and then widening again to $8 \mathrm{~km}$ southeast of Point Conception with a shelf break at the $100 \mathrm{~m}$ isobath. Although some deep gullies are present near the eastern edge of the basin and discontinuous distributary channels are located on a submarine fan, the Conception fan, along the western flank of the basin is essentially canyonless and conduits do not appear active (Fischer and Cherven, 1998).

Numerous faults and folds exist in the Santa Barbara Basin and generally trend East-West (Fig. 2a). The faults along the southern flank of the basin, near the base of the Channel Islands platform, exhibit normal displacements while those concentrated along the northern flank are reverse or thrust faults (Yerkes et al., 1981; Richmond et al., 1981; Burdick and Richman, 1982; Vedder et al., 1986; McCulloch, 1989; Sorlien et al., 1999, 2000; Keller and Gurrola, 2000; Eichhubl et al., 2002). The Santa Cruz Island Fault is a rightlateral strike-slip fault, which offsets Santa Cruz Island along its east-west axis. The major reverse or thrust faults along the northern flank of the Santa Barbara Channel are, from west to east, the South Santa Ynez, North Channel Slope, Red Mountain, Pitas Point and Oak Ridge faults (Fig. 2a). These faults, including the Santa Cruz Island Fault, are considered active (Greene, 1976; Bortugno, 1977; Yerkes et al., 1981; Pinter and Sorlien, 1991; Jennings, 1994). Compressional deformation associated with fault movement in the Santa Barbara Basin is best illustrated by an uplifted and folded (anticlinal) block, known as the Mid-Channel Trend, located in the eastern part of the basin and bounded by faults of the Oak Ridge fault zone (Fig. 2b). This feature is the westward or offshore extension of the Oak Ridge anticlinorium mapped onshore north of Ventura (Greene, 1976; Greene et al., 1978; Yerkes et al. 1981; Vedder et al., 1989; Eichhubl et al., 2000, 2002).

Many earthquakes have been recorded in the Santa Barbara Basin region (Yerkes et al., 1981) and 15 earthquakes 


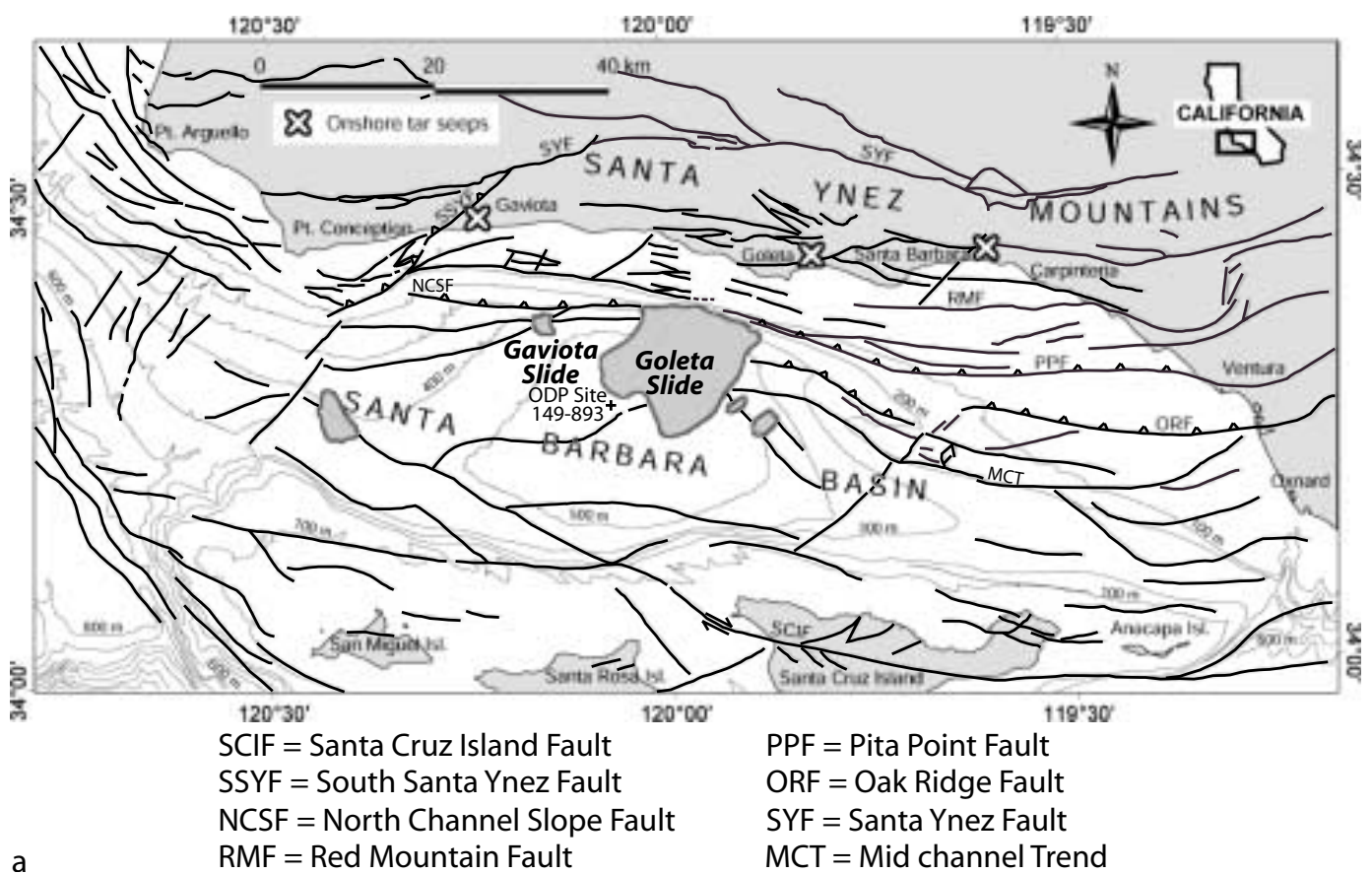

a
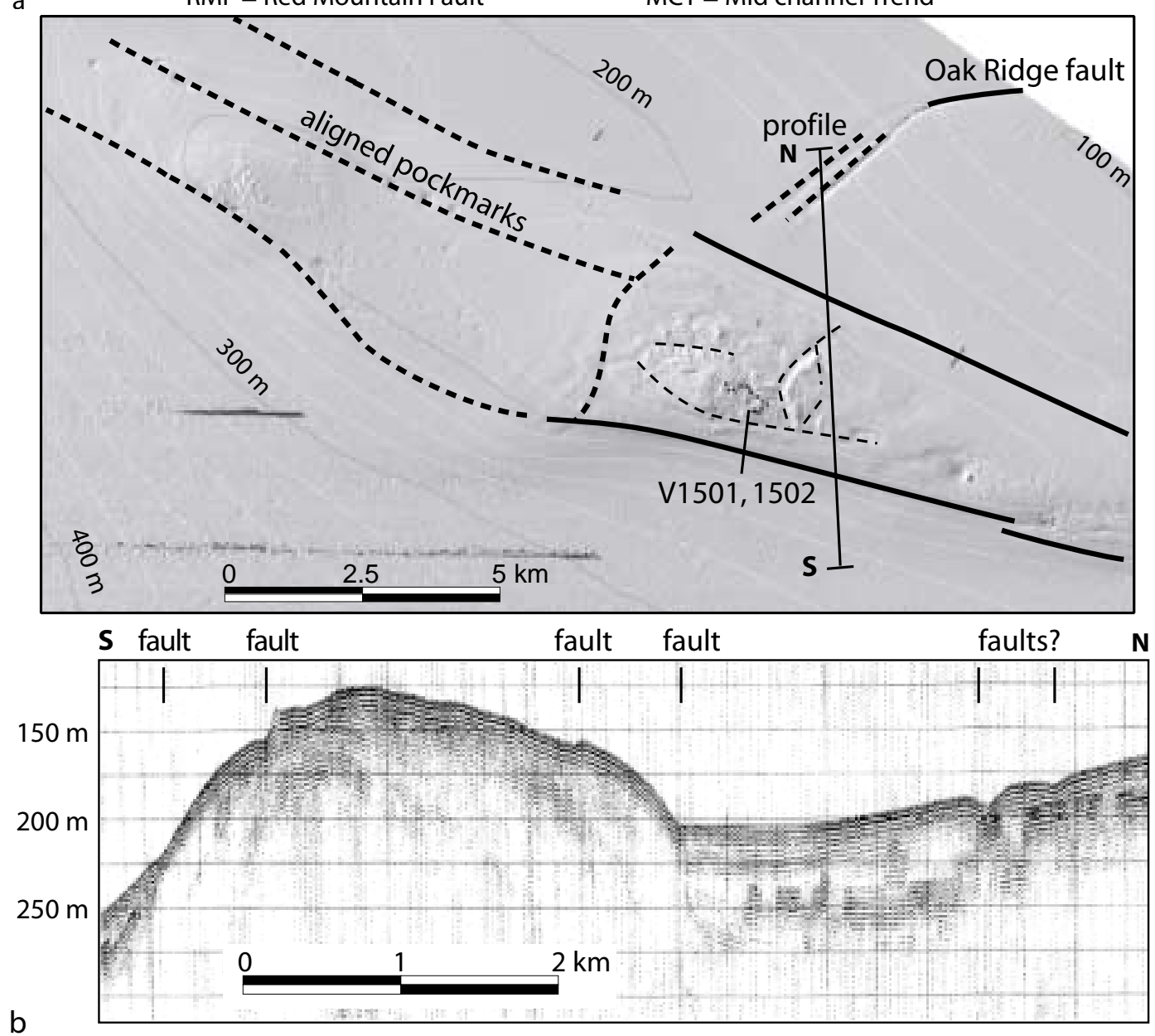

Fig. 2. Fault map of the Southern California Borderland showing: (a) major geologic structures in the Santa Barbara Channel region and (b) EM300 multibeam bathymetric image of, and seismic reflection profile across, the Mid-Channel Trend (Santa Clara Ridge of Thornton, 1984), a major anticlinorium with seafloor expression in eastern Santa Barbara Channel. Modified after Eichhubl et al. (2002). Short dashed lines show tract of "Ventana" dives V1501 and V1502. 


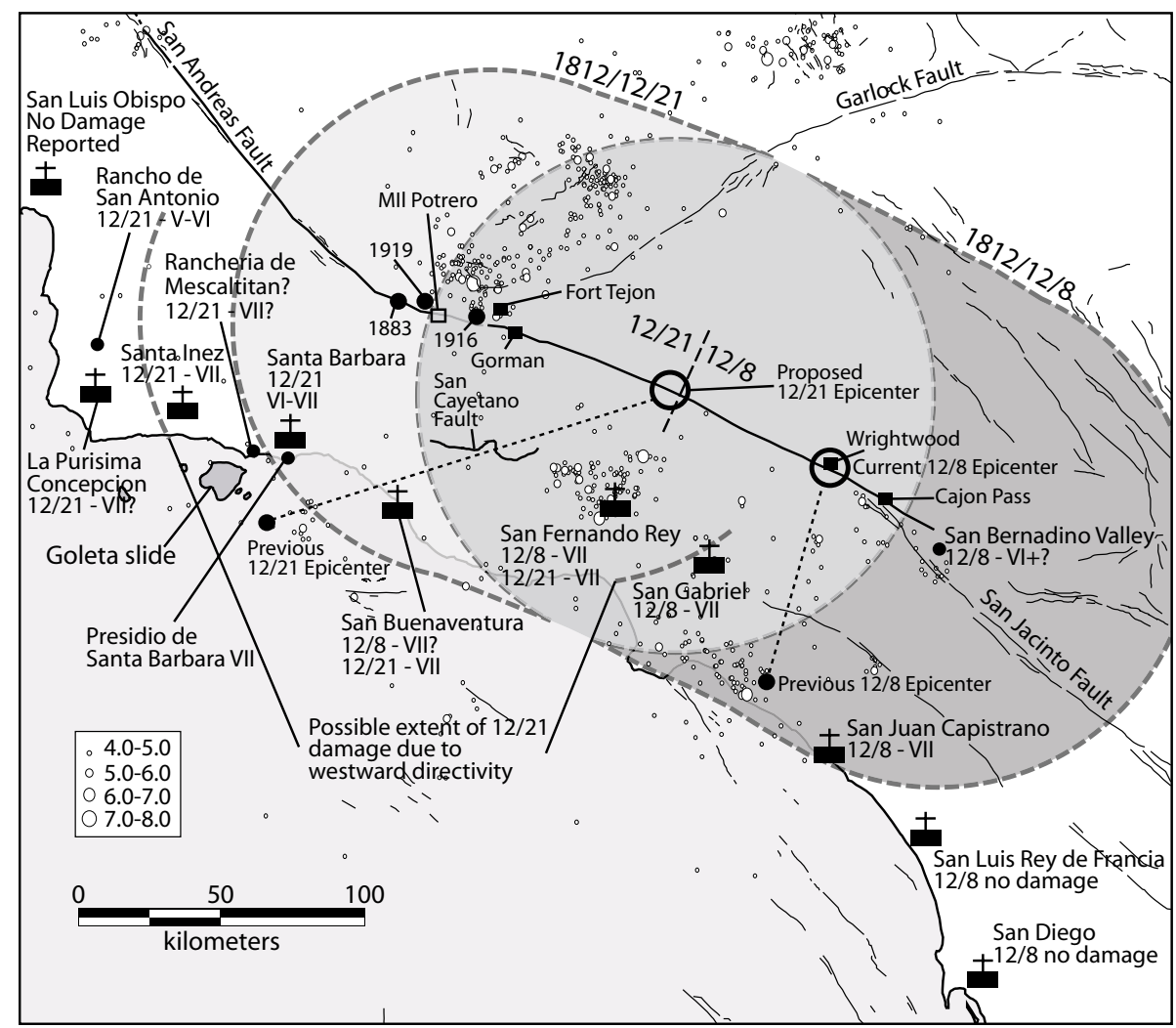

Fig. 3. Earthquake epicenter locations, re-locations, and Modified Mercali Intensity zones based on California Mission records of felt earthquakes. Modified after Toppozada et al. (1981, 2003). Dots represent earthquake epicenters; blocks with crosses show location of Missions.

equal to or greater than M5.0 that occurred between 1800 and 1999 have been mapped in the immediate area (Toppozada et al., 2000) and indicate that active tectonic deformation is ongoing. Fault-plane solutions indicate a general reverse leftoblique slip on the east-west trending faults along the northern basin flank (Yerkes et al., 1981). The largest historical earthquakes within the Santa Barbara Basin region occurred in 1812 (M7.1 and 7.5) and 1925 (M6.8). The epicenters for both of these earthquakes had been located in the central part of the basin (Toppozada et al., 2000) near the base of the northern flank (Fig. 3). However, recent work by Dolan and Rockwell (2001) along the San Cayetano fault onshore in the Santa Ynez Mountains shows $4.5 \mathrm{~m}$ of reverse slip offset on a very young surface rupture within historical alluvium. The amount of slip on this fault suggests it was created by a M7.2-7.5 earthquake. Dolan and Rockwell (2001) speculate that since the rupture surface is overlain with historical alluvium and carbon 14 analyses gives a post- 1660 date that it could represent the source for the 21 December 1812 event. Also, Toppozada et al. (2002), based on California Mission records of recorded intensities and damage caused by earthquakes relocated the earthquake epicenters of 1812 and propose that they occurred along the San Andreas Fault rather than along a fault within the Santa Barbara Channel (Fig. 3).

\section{Methods}

Several methods were used to investigate the mass movement features within the Santa Barbara Basin including the interpretation of digital multibeam bathymetric images, seismic reflection profiles, and in situ observations and seafloor sampling using Remotely Operated Vehicles (ROVs). In addition, we utilized the results of ongoing investigations into fluid flow and sedimentation within this highly productive hydrocarbon provenance.

\subsection{Multibeam bathymetry and backscatter data}

High-resolution multibeam bathymetric and backscatter data using a $30 \mathrm{kHz}$ Simrad EM300 hull-mounted adjustableangle sonar on board the R/V "Ocean Alert" by C\&C Technologies, under contract to the Monterey Bay Aquarium Research Institute (MBARI) were used in this study. Shorebased differential GPS provided positioning with an estimated accuracy of $<3 \mathrm{~m}$. The multibeam system consisted of an array of 130 beams that is adjustable between $80^{\circ}$ to $150^{\circ}$ to compensate for changes in swath width with variations in water depth. A $1^{\circ}$ beam width $\left(2^{\circ}\right.$ at water depth $\left.<250 \mathrm{~m}\right)$ gave a sonic footprint of about 3\% of water depth. Depth was determined by a combination of phase and amplitude detection, resulting in vertical and horizontal resolution of $0.2 \%$ 


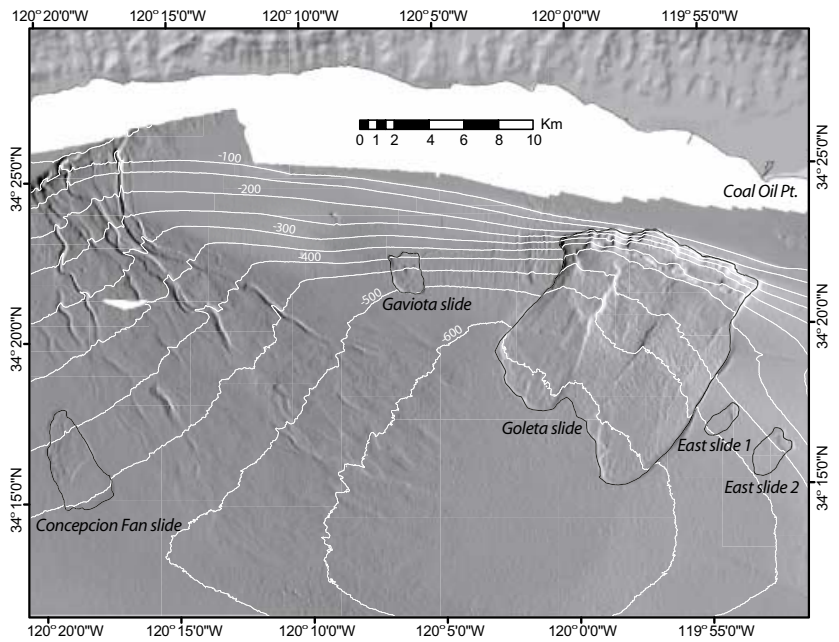

Fig. 4. Detailed map of seafloor morphology of the Santa Barbara Basin. Computer generated hill shaded bathymetric image based on EM300 multibeam bathymetry.

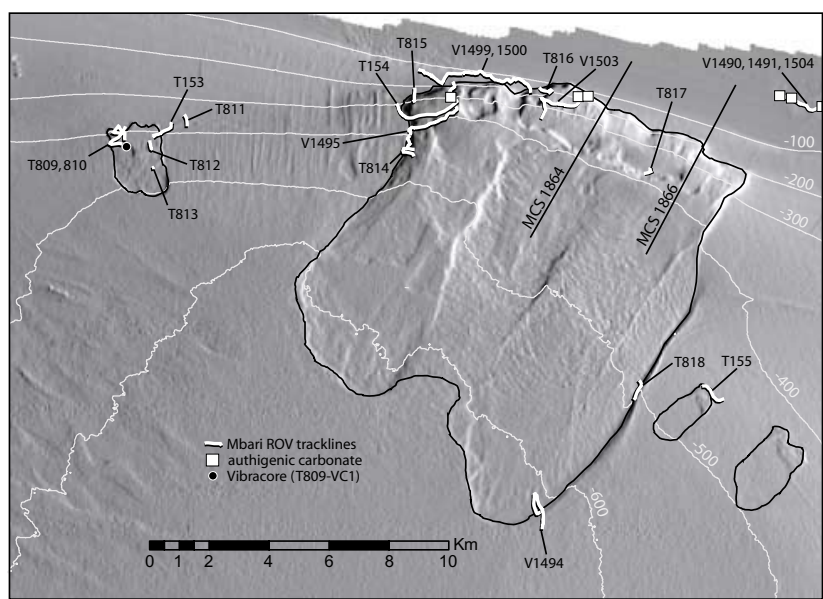

Fig. 5. Map showing locations and track lines of MBARI ROVs "Tiburon" and "Ventana" transects and location of USGS seismic reflection profiles along the northern flank of Santa Barbara Basin.

and $2 \%$ of water depth, respectively. The mapped area generally extends from Latitude $34^{\circ} 10^{\prime} \mathrm{N}$ to Latitude $34^{\circ} 27^{\prime} \mathrm{N}$ and Longitude $120^{\circ} 30^{\prime} \mathrm{W}$ to Longitude $120^{\circ} 32^{\prime} \mathrm{N}$ covering an area of over $3000 \mathrm{~km}^{2}$. Due to the limited swath width at water depths of less than $100 \mathrm{~m}$, the northern and southern boundaries of the mapped area follow approximately the break of the mainland and island shelves (Fig. 1). Bathymetric and backscatter data were gridded and mosaiced using software by Larry Meyer and John Hughes Clarke, University of New Brunswick. The whole data set was binned to a 20-m grid, and selected shelf regions to a 5-m grid. Shaded relief images were produced using $\operatorname{ArcInfo}^{\circledR}$ and the 3-D rendering software Fledermaus (i.e. Fig. 4). Final processing of the data was done using the software package MB-System. Several bathymetric grids and acoustic backscatter images of multiple resolutions were created for the survey area, includ-

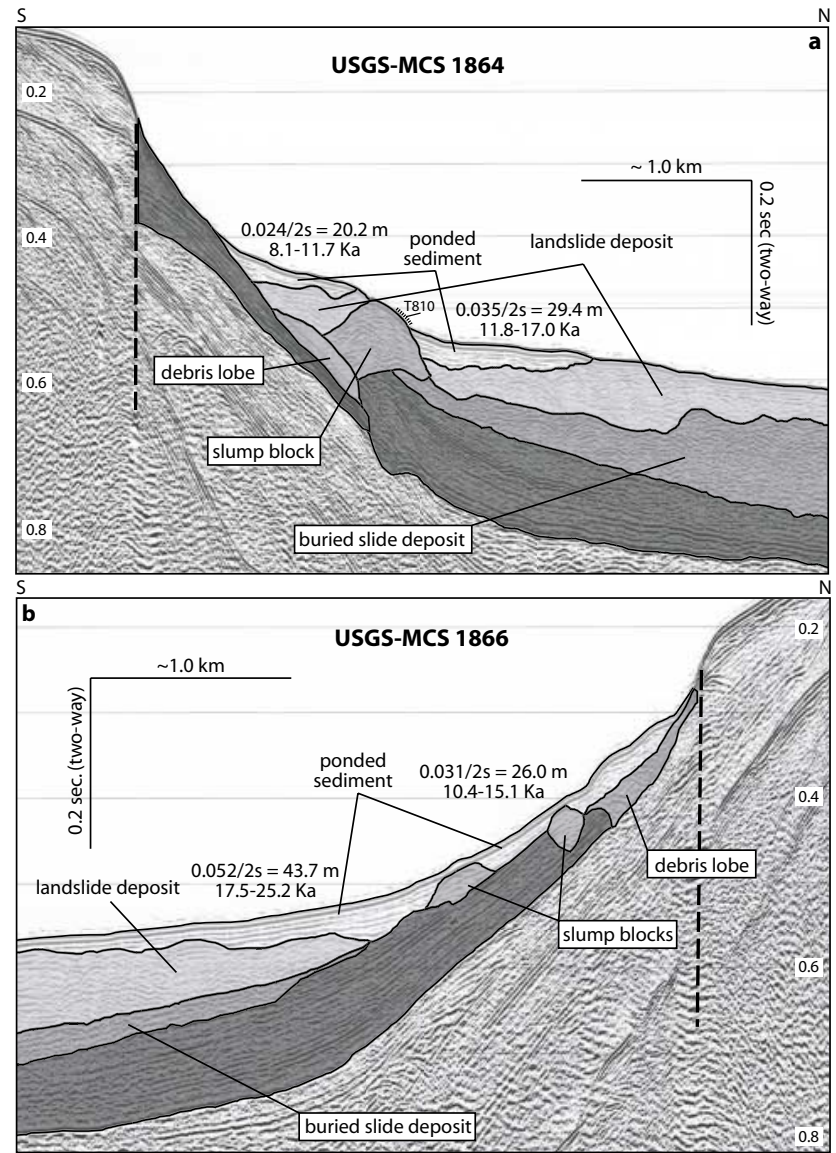

Fig. 6. Interpreted seismic reflection profiles collected by the USGS and map showing locations of track lines: (a) USGS Line 1864. (b) USGS Line 1866. See Fig. 5 for track line locations.

ing the area of our interest along the northern flank of the Santa Barbara Basin. The resolution of the data sets produced from the latest processing range from 40 to $25 \mathrm{~m}$ grid cells (or 20 to $15 \mathrm{~m}$ acoustic backscatter pixel sizes) depending on water depth. This data set is published in a CD-ROM (MBARI Seafloor Mapping Team, 2001).

\subsection{Seismic reflection profile data}

Additional high-resolution and intermediate penetration multi-channel seismic reflection data were collected by the USGS across the Goleta slide (Fisher et al., 2005a; Figs. 5 and 6). Several lines of the USGS high-resolution $2 \mathrm{KJ}$ minisparker 24 fold $1.5-1.7 \mathrm{kHz}$ seismic reflection profiles were stacked and deconvolved and used in the interpretation of the subsurface part of the Goleta slide (Fig. 6). These data are part of a larger data set that were collected in the Santa Barbara Channel by the USGS in 2002 and reported upon by Fisher et al. (2005a). 


\subsection{ROV investigations}

Selected morphologic features of the northern margin of the Santa Barbara Basin were examined visually and seafloor samples collected using MBARI's ROVs "Tiburon" and "Ventana". "Ventana" dives were made from the R/V "Point Lobos" over a 10-day period in October 1998, while the "Tiburon" dives were made from the R/V "Western Flyer" during a three-day period in May 2001 and in a five-day period in February 2005. Dive observations using closedcircuit digital video were complemented with shipboard and shore-based analyses of grab samples and shallow $(<1 \mathrm{~m})$ sediment push cores collected during the ROV dives. "Ventana" is an ROV capable of diving to a depth of $1850 \mathrm{~m}$ and can collect push core sediment samples (20 cm deep), rock samples, and video. "Tiburon" is capable of reaching a depth of $4000 \mathrm{~m}$ and also is able to obtain a like suite of data as well as longer $(80-90 \mathrm{~cm})$ vibra-cores. Vibra-cores were collected during February 2005 as part of an engineering study and will be reported upon at a later date, but several cores shed light upon this investigation and are reported herein.

In 1998 "Ventana" dive V1494 was made on the toe of the eastern lobe of Goleta slide and "Tiburon" dive T818 of February 2005 was made along the apparent erosional edge of the eastern lobe in the gully that runs along the area of accumulation (Fig. 5). "Ventana" dives V1495, V1499, V1500 and V1503 of October 1998 were made along the head walls of the western and central segments of the slide during MBARI's "Point Lobos" cruises of October 1998 (Fig. 5). In addition, in February 2005 "Tiburon" dives T814, T815, T816, and T817 where made in the headward parts of the western, central and eastern heads of the Goleta slide. In 2001, and again in 2005, "Tiburon" dives T153, T809, $\mathrm{T} 810$, and T812 were made along the headward parts of the Gaviota slide with "Tiburon" dive T813 located in the zone of accumulation of the eastern lobe of the slide. "Tiburon" dive T153 and T811 was made in the propagating crack.

\section{Tsunamis}

In 1812 three large earthquakes occurred in the Santa Barbara region, two of magnitude 7.1 and 7.5 on 8 December and one, magnitude 6.8 , on 21 December with aftershocks lasting until April 1813 (Toppozada, 2002). These earthquakes caused extensive damages from San Juan Capistrano to San Diego. There were several reports of sea waves that may have been associated with these earthquakes. Senan (1813) reported upon a sea inundation at the Rancheria de Mescaltitan in Santa Barbara (Fig. 3) stating, "People from the Rancheria are living on the plains around the Mission, to where they withdrew since they were very close to the ocean, which threatened to flood them." In this same document Senan (1813) reported upon a similar effect in San Buenaventura (Ventura) where he stated, “... it has been necessary for us to withdraw for now, for somewhat more than half a league inland, for fear of the ocean, which we knew had flooded in two parts" (Toppozada et al., 2002). Englehardt (1897) also reported upon the fear of ocean inundation at Buenaventura. In addition, Toppozada et al. (2002) reported upon some less reliable reports (Trask, 1856; Bancroft, 1888) written many years after the earthquakes that reported upon the sea waves. One such incident reported occurred at Refugio where it was said that "... a ship was carried up a canyon by the wave and returned to the sea" (Townley and Allen, 1939). Another incident, reported by Trask $(1856,1864)$ states that “... an immense wave flowed 1 to 2 miles inland near Refugio but did little damage." Toppozada et al. (1981) concluded from these reports that sea waves were associated with the earthquakes of 1812. They speculated that the source of the sea waves is a tsunami or seiche or a submarine landslide that occurred in the Santa Barbara Channel.

\section{Fluid flow}

The Santa Barbara Basin is a major active hydrocarbon province with many producing platforms (Fig. 1), although production is declining. Evidence of active and dormant fluid seeps in the Santa Barbara Basin have been observed as active venting of gas and oil, bacterial mats, precipitates of authigenic carbonate, and mud and tar volcanoes (Eichhubl et al., 2000, 2002). The Cretaceous to Holocene sequence of clastic and hemipelagic sedimentary units mapped in and adjacent to the basin includes organic-rich siliceous mudstones of the Miocene Monterey Formation that is both a source and a fractured reservoir of hydrocarbons (Issacs, 1981). Eichhubl et al. (2000) state that while the northern flanks of the basin, being part of the southern Santa Ynez Mountains, are rising, the central part of the basin is undergoing sedimentation and progradational burial. This progadational burial, as well as diagenesis, in the synclines, produced from the transpressive shortening of the basin, drive hydrocarbon generation and pore fluid expulsion, leading to submarine venting and seeping of natural gas and oil (Vernon and Slater, 1963; Allen et al., 1970; Wilkinson, 1972; Fischer and Stevenson, 1973).

Due to the low matrix permeability of the Miocene Monterey Formation siliceous mudstones, fluid flow within the Monterey Formation and adjoining younger strata of the Santa Barbara region depend on the presence of conductive fractures and faults (Eichhubl et al., 2000; Eichhubl and Boles, 2000a). Evidence of past focused fluid flow along faults is seen in surface outcrops and core samples collected across faults onshore that are extensively cemented with carbonate (Eichhubl and Behl, 1998; Eichhubl and Boles, 1997) and offshore along the southern branch of the Santa Ynez fault zone (Fig. 7). Based on mass balance estimates of the fluids involved in fault cementation, Eichhubl and Boles (2000b) inferred that faults channel fluid migrating up along the tilted flank strata of the basin, providing crossstratigraphic pathways for fluid expulsion to higher stratigraphic levels and to the surface. 


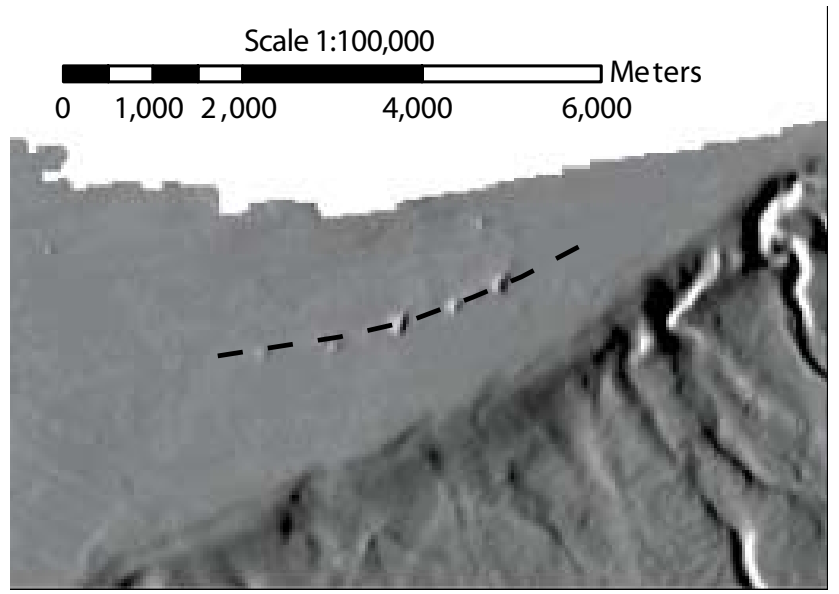

Fig. 7. EM 300 multibeam bathymetric image showing alignment of possible carbonate mounds along the offshore trend of the South Santa Ynez Fault (dashed line).
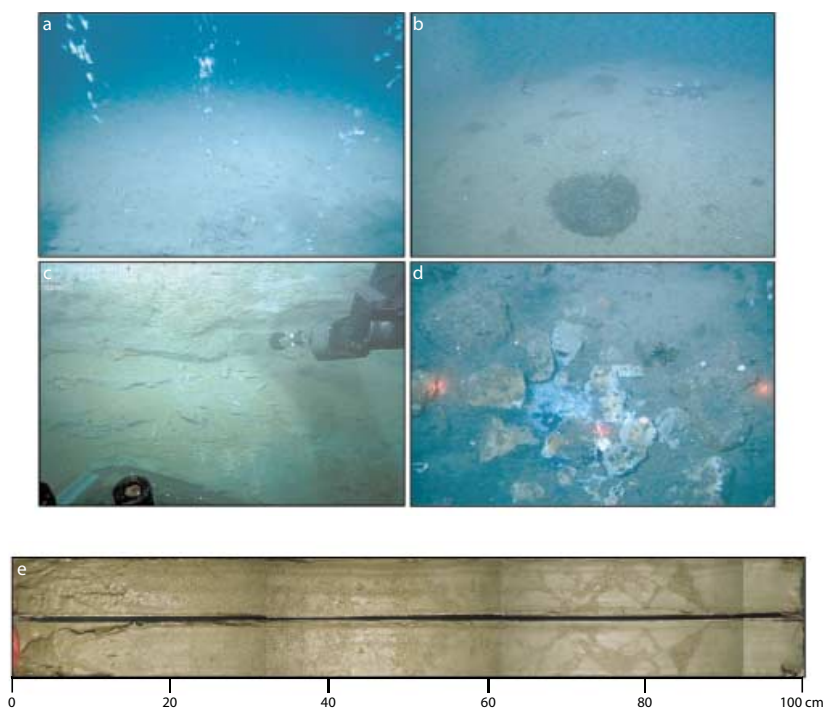

Fig. 8. Photos obtained during MBARI ROV dives: (a) photo of bubbles seeping out of seafloor in Santa Barbara shelf near the head of the Goleta slide complex (photo width $\sim 1 \mathrm{~m}$ ), (b) tar paddy ( $\sim 20 \mathrm{~cm}$ in diameter) on mud volcano with gas bubbles NW of Gaviota slide, (c) head scarp of Gaviota slide (push core $\sim 20 \mathrm{~cm}$ long), (d) bacterial mat in zone of excavation near head of Gaviota slide (distance between laser dots $\sim 20 \mathrm{~cm}$ ), (e) split vibracore taken in head of Goleta slide during ROV dive T809 showing chaotic landslide deposits below $50 \mathrm{~cm}$ mark; note smooth light gray mud surface at $\sim 95 \mathrm{~cm}$, possible slide plain.

As part of this study we used MBARI's ROVs "Tiburon" and "Ventana" to observe active hydrocarbon seeps within the Santa Barbara Basin. These seeps occur predominately in areas where bedrock is either exposed or thinly covered with Holocene sediment, specifically on the northern shelf of the Santa Barbara Channel and on the Mid-Channel Trend, a structural and morphologic high in the eastern part of the channel (Figs. 2b and 8a). The seeps we observed are contin-

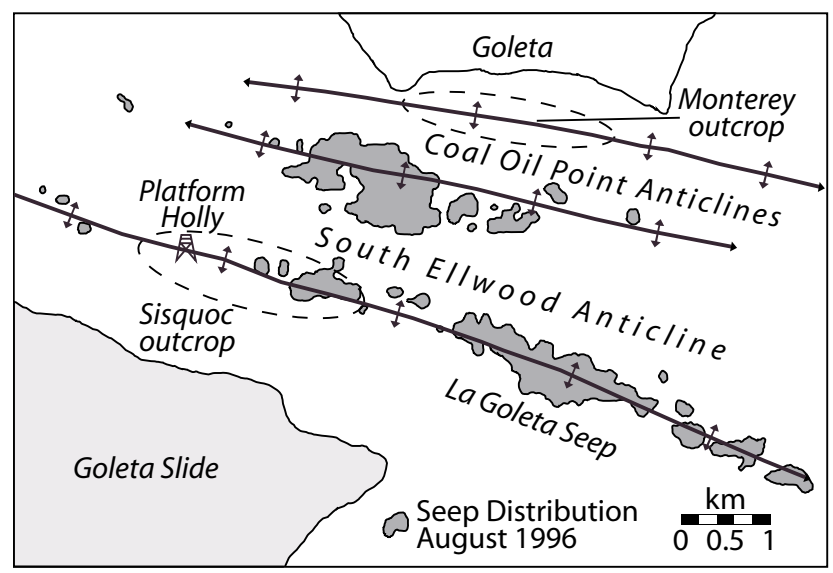

Fig. 9. Structure and gas venting sites on the northern continental shelf adjacent to the head of Goleta slide. Modified after Quigley et al. (1999).

uous or intermittent and release gas bubbles and to a lesser extent oil droplets from crevices in rocky substrate or from circular openings within muddy substrate. At Coal Oil Point, gas seeps occur along two linear trends following faulted anticlines that trap hydrocarbons in the fractured Monterey Formation (Quigley et al., 1999; Fig. 9). South of Gaviota, active gas seeps were observed from a series of mud volcanoes, measuring about $10 \mathrm{~m}$ in diameter and $4 \mathrm{~m}$ high (Fig. $8 \mathrm{~b}$ ). Less vigorous gas venting was observed at several locations along the head scarp of the Goleta slump (Fig. 8a). Joan et al. (2000) stated that Beggiatoa sp. bacterial mats suggest a low flux of methane and Eichhubl et al. (2000) suggested the same thing based on the high sulfide and alkalinity values of pore water that they extracted from shallow sediment cores within the mats. In addition to the active vent sites, evidence of slow seeping rates were found at the toe of Goleta slide and along the linear depression leading away from the southern edge of the Goleta slide as well as at the base of a fairly consolidated head scarp of Gaviota slide (Figs. 8c, d).

Keller (1995) and Eichhubl et al. (2000, 2002) conclude that active gas venting in the Santa Barbara Basin is clearly controlled by subsurface structures such as faults and faulted anticlines. At Coal Oil Point, the Molino-Gaviota, Coal Oil Point, and South Ellwood anticlines located inshore (east) of the head of the Gaviota slide (Fig. 9) exhibit a remarkable trend of gas venting from the underlying reservoirs. Fault control of the hydrocarbon fluid flow is consistent with the model of focused basinal fluid migration along faults as inferred from outcrop and core observations (Eichhubl et al., 2000). The head scarp of Goleta slump where evidence of increase venting was observed does indeed follow regional fault and anticlinal trends (Fig. 9).

\section{Sedimentation}

The mainland shelf and the western flank of the Santa Barbara Basin is the area of highest sedimentation within 


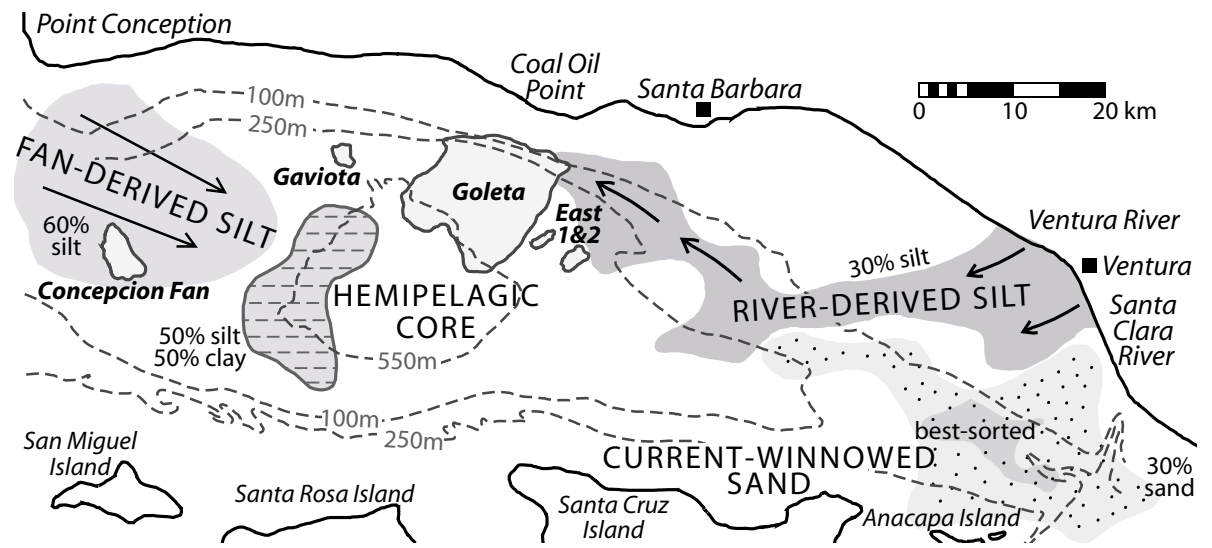

Fig. 10. Map showing distribution of sediment during times of floods. Modified after Thornton (1984).

the Santa Barbara Channel region. Approximately 90\% of terrigenous sediment input into the region is from point sources comprised of the Ventura and Santa Clara rivers located east of our study site with the remainder $(\sim 10 \%)$ coming from coastal streams, shoreline erosion and from the west around Point Conception to Conception fan (Fleischer, 1972; Thornton, 1984). Thornton (1984) completed very comprehensive analyses of the relative importance, dispersal pathways, and patterns of transport of fine-grained sediment based on the analyses of piston cores. This sediment input is fine-grained with most of the basin beneath $200 \mathrm{~m}$ water depth containing less than $10 \%$ sand. Previous workers have shown that sediment is distributed primarily by the Anacapa Current, a strong $(25 \mathrm{~cm} / \mathrm{s})$ west-northwest 200 m-thick current that flows toward Coal Oil Point (Kolpak, 1971; Drake et al., 1971; Pirie and Steller, 1977; Edwards and Gorsline, 1978; Thornton, 1981). The fine-grain sediment distribution and winnowing pattern of this current is illustrated by the $70 \%$ silt isopleth that shows current distribution as a finger emanating from the Hueneme sill and pointing northwest (Fig. 10). Flood plumes emanating from the Ventura and Santa Clara rivers show a similar pattern of sediment distribution (Fig. 10; Thornton, 1984). The fine-grained sediment (silt and mud) accumulate along the western flank of the Santa Barbara Basin having been swept northwestward along the shelf and over the shelf break to produce a prograding-like shelf edge. Calculated sediment accumulation rates along the western flank of the Santa Barbara Basin range from $173 \mathrm{~cm} / \mathrm{Ka}$ to $200-250 \mathrm{~cm} / \mathrm{Ka}$, at the lower to mid-slope areas (Thornton, 1984; Edwards et al., 1995; Eichhubl et al., 2002) and 0.8 to $1.9 \mathrm{~cm} / \mathrm{ky}$ in the vicinity of Gaviota slide (Lee at al., 2004).

\section{Mass wasting}

The EM300 multibeam bathymetry and backscatter data collected in the Santa Barbara Basin images the seafloor morphology in much greater detail than has been shown previously (Fig. 4). These data show mass wasting features com- prised of rills, sediment flows and slumps. Seven distinct mass movement features that compare in location, but not in geometry to Thornton's $(1984,1986)$ flows A and C through $\mathrm{H}$ (his flows B and I not seen) have been imaged. The largest mass movement feature, and the dominant geomorphic feature in the region is the $134-\mathrm{km}^{2}$ Golita slide complex whose head scar is located $5 \mathrm{~km}$ offshore (northwest) of Coal Oil Point near the town of Goleta, which is located $6 \mathrm{~km}$ west of Santa Barbara. The second and third largest features are located at the base of the southern flank of the Santa Barbara Basin north of San Miguel and Santa Rosa islands, slides C $\left(\sim 20 \mathrm{~km}^{2}\right)$ and $\mathrm{D}\left(\sim 24 \mathrm{~km}^{2}\right)$ of Thornton (1984), but were not found in the MBARI multibeam bathymetry and may be buried. On the mid-slope of the western margin of the Santa Barbara Basin an $\sim 14 \mathrm{~km}^{2}$ landslide exists, slide A of Thornton (1984), that is the fourth largest mass movement feature in the region. A landslide called here the East slide 2 is the fifth largest $\left(4.15 \mathrm{~km}^{2}\right)$ in the region and lies on the midslope of the southwestern flank of the Mid-Channel Trend, approximately $5 \mathrm{~km}$ southeast of the main body of Goleta slide (Fig. 4). The next largest feature is on the western flank, but the best described and most studied mass movement feature in the region, is the Gaviota slide located $10 \mathrm{~km}$ offshore (due south) of Gaviota Point and $8 \mathrm{~km}$ due west of the main body of the Goleta slide (Lee and Edward, 1986; Edwards et al., 1995; Hampton et al., 1996). Other smaller mass movement features and rills or gullies are scattered about the midto lower-slope of the northern flank of the basin and a zone of intense gullies, longitudinal cracks and incipient slides exist between the Goleta slide and Gaviota slide. We use the terminology of Varnes (1978) as modified by Edwards et al. (1995) and Hampton et al. (1996) to describe mass movement components in this paper.

\subsection{Goleta slide}

The Goleta slide is a complex compound slide that is $14.6 \mathrm{~km}$ long and $10.5 \mathrm{~km}$ wide with the latest seafloor surface displacement volume of $1.51 \mathrm{~km}^{3}$ (Fig. 11a). It has as many as 24 individual minor or major flow lobes and slump blocks 

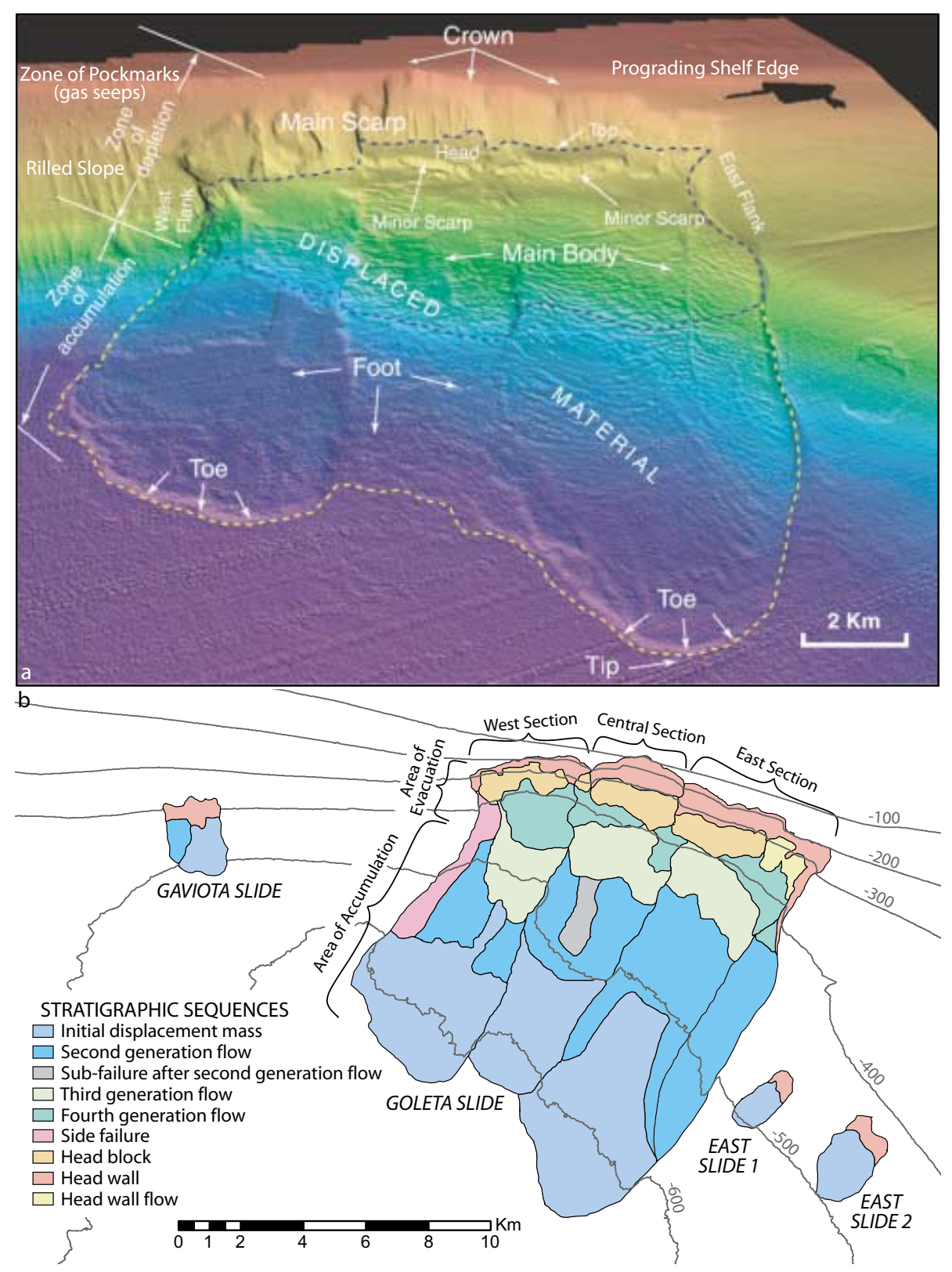

Fig. 11. The Goleta slide complex: (a) slope shaded EM300 multibeam bathymetric image showing multiple lobes, failure masses, slump blocks, and scars of the Goleta slide; classification of Goleta slide is made using terminology of Varnes (1978), (b) sub-components of Goleta and other slides in the Santa Barbara Channel showing the many lobes, flows, and blocks that produce this complex compound mass movement feature.

expressed on the surface of the slide (Fig. 11b). The slide can be divided into three major segments (lobes), the eastern, central and western segments, that are comprised of distinct head scars, blocks, secondary deposits, and displaced masses (Fig. 11). Seismic reflection profiles show multiple subsurface failures identified by buried packages of chaotic reflectors that have a very irregular hummocky surface overlain by acoustically transparent units. This stratigraphy is illustrated on the USGS seismic reflection profiles (Fig. 6; Fisher et al., 2005a).

\subsubsection{Eastern segment}

The eastern segment is the largest of the three distinct surface lobes mapped (Figs. 11 and 12) with the top of its $150 \mathrm{~m}$ high head or main scarp located in $150 \mathrm{~m}$ of water and a fairly intact head block and debris lobe at the base of the scar. The head block covers an area of $\sim 1.2 \mathrm{~km}^{2}$, has a minor scarp of $20 \mathrm{~m}$ high giving it a volume of $\sim 0.24 \mathrm{~km}^{3}$. The head block is not laterally continuous across the base of the head scarp with about the eastern third of the base being composed of two distinct headwall flows rather than a head block. A flow 
apron of displaced material separates the head block and debris lobe from the minor scarp in the mid-eastern part of the zone of evacuation. The main scarp and depletion zone appear as a generally smooth, hummocky surface with many transverse ridges (compression ridges) that extend to a water depth of about $450 \mathrm{~m}$. A very lobate-shaped displacement mass comprises the main body of the slide in the zone of accumulation. Here the displaced material is divided into two sections, the main mass and a narrow secondary side mass that probably resulted from differential movement between the two sections (Figs. 11 and 12). Both sections exhibit distinct well-developed transverse or compression ridges, indicators of a pulsing flow (Lee et al., 1993). The eastern boundary of this two-section displacement mass is defined by a deep narrow gully that converges with an east-trending rill near the top of the main body of the slide (Fig. 12) and shows distinct bedforms (i.e., sediment waves) at its mouth and levee morphology on top of the landslide deposit along its western lobe, indicative of sediment transport or strong currents flowing down the gully. At the boundary between the zone of depletion and zone of accumulation an east-west trending gully located on the slope east of the Goleta slide appears to have been cut-off by the slide. This gully lies above, and is parallel to, the subsurface mapped Pitas Point-Ventura fault (Vedder et al., 1986; Fisher et al., 2005a). The toe at the eastern lobe is hummocky to smooth and lies at a depth of $574 \mathrm{~m}$ and rises $9-10 \mathrm{~m}$ above the undisturbed sediment. Inclination of the head scarp is $40^{\circ}$ to $45^{\circ}$ with the slope just at the base of the scarp reaching $27^{\circ}$ that then flattens to $1.5^{\circ}$ near the toe. The overall head to toe average is $2^{\circ}$.

The seismic reflection profiles (Figs. 5 and 6) indicate that the eastern lobe was deposited above at least 5 previous slide deposits (Fisher et al., 2005a). Interpretation of the seismic reflection profiles indicates the flat shelf seafloor north (landward) of the eastern segment head scarp is underlain by steep $\left(\sim 20^{\circ}\right)$ southward dipping beds of probable Miocene Monterey Formation rocks. Two intact slump blocks are imaged in USGS Line 1866, which are located between the base of the head scarp and the upper part of the slide mass. One significant observation made from the seismic reflection profiles is that the slump block appears to have dammed sediment behind it after it came to rest at the base of the head scarp of the center lobe (Figs. 6a, b). These data nicely image buried slide deposits and blocks indicating that multiple failures have occurred in the past with at least four stacked sequences shown.

"Tiburon" ROV dive T1494 was made on 7 October 1998 and traversed from south to north across the eastern toe of the eastern lobe and back south again to the base of the toe's tip (Fig. 5). At the start of the transect, outside of the slide, white bacterial mats were found and sampled. The base of the slide toe was easily identified from a $\sim 2 \mathrm{~m}$ high scarp. From this scarp the toe rises another $2 \mathrm{~m}$ to the tip. The transect into the displaced material of the eastern lobe encountered up to 4 small, yet distinct bacterial mats and mounds. However, no gas seeps were seen and the seafloor was covered with mud. Tiburon dive T818 of February 2005 was made down into the gully that runs along the area of accumulation of the

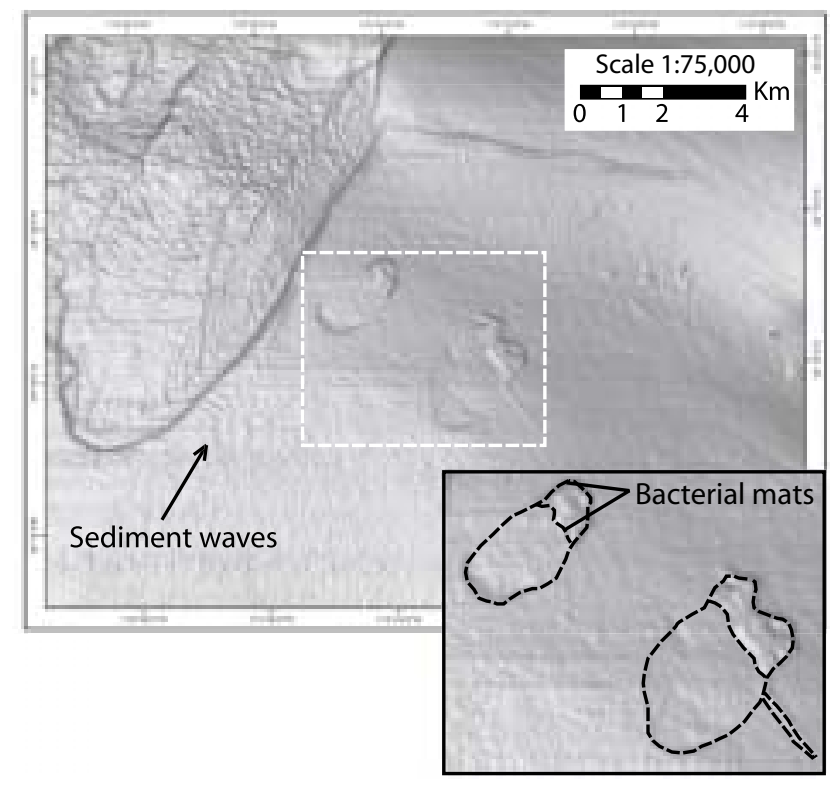

Fig. 12. EM $30030 \mathrm{kHz}$ multibeam slope-shaded bathymetry of the eastern lobe of Gaviota slide and adjoining area showing East slides 1 and 2. Note evidence (sediment waves) of sediment or current flow down channel that delineates the eastern edge of the eastern lobe of Goleta slide.

eastern lobe where mainly a mud covered floor was found and no evidence of recent erosion was seen. The head scarp of the eastern segment of Goleta slide complex was not investigated by ROV, but a secondary scarp was briefly visited during Tiburon dive T810 to determine if any slump block material was exposed (Figs. 5 and 6a). Unfortunately the slope was mud covered and no slump material was found. Gas seeps were observed within $2.5 \mathrm{~km}$ of the head scarp of the Goleta slide's eastern segment during Tiburon dives T1490, T1491, and T1504 (Figs. 5 and 8a). Here extensive curtains of gas were observed venting from the sea floor.

\subsubsection{Central segment}

The central segment is shorter and narrower than the other two segments and appears to have erosional scarps forming the sides of the displaced material in the zone of depletion (Fig. 11). The top of the 200-m high head scarp lies in $90 \mathrm{~m}$ of water and has a well-defined head block at the base that lies between $300 \mathrm{~m}$ and $400 \mathrm{~m}$ of water and covers an area of $\sim 0.56 \mathrm{~km}^{2}$. The head scarp itself is heavily gullied containing a higher $\left(\sim 13 / \mathrm{km}^{2}\right)$ density of gullies per area than either the eastern $\left(\sim 11 / \mathrm{km}^{2}\right)$ or western lobes $\left(\sim 2 / \mathrm{km}^{2}\right)$. Below the head block the zone of depletion is generally smooth with the lower part containing transverse or compression ridges, similar to the eastern lobe. Along the base of the secondary scarp, a smooth surfaced sediment flow with a distinct toe appears to have flowed out from the west, from the western segment head scarp, to cover a portion of the central segment debris apron. Runout of the central lobe is shorter than those lobes on either side with the apparent toe at a depth of about 


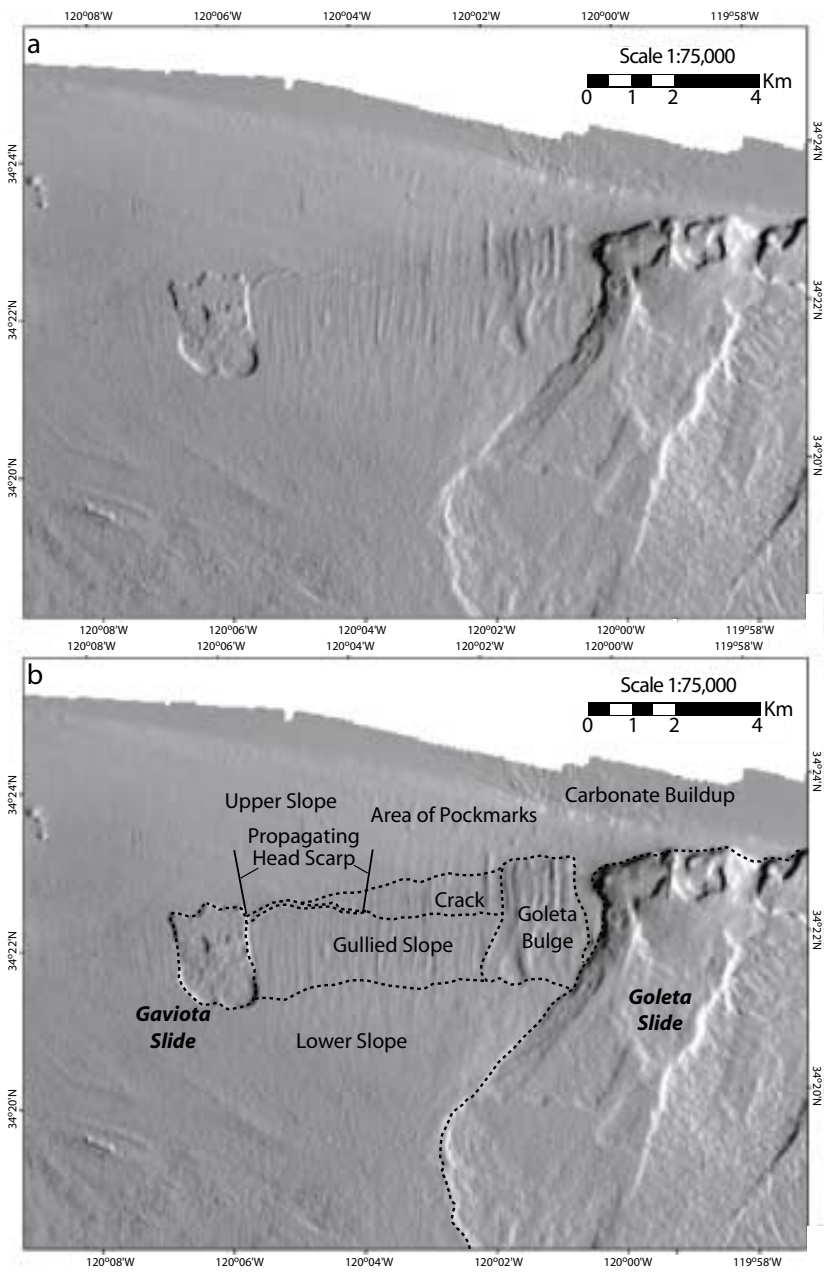

Fig. 13. The Western segment of Goleta slide and propagating crack: (a) slope shaded EM300 multibeam bathymetry showing the western lobe of Goleta slide and adjoining area including the Gaviota slide (mudflow of Edwards et al., 1975) and propagating head crack, (b) interpretations of morphologic features.

$560 \mathrm{~m}$. A small $\left(4.97 \mathrm{~km}^{2}\right.$ in area) secondary flow is seen in the displaced material of the lower zone of depletion. The toe is less distinct with no raised tip, but appears to have a larger area of disturbed sediment in front of its toe than seen in the western lobe.

Inclination of the main scarp is generally less than found at the head scarp of the eastern lobe with a lower scarp angle of $11^{\circ}$ and an upper scarp angle of $40^{\circ}$ to $45^{\circ}$ that then flattens to $0.7^{\circ}$ near the toe. The overall head to toe average is $8.5^{\circ}$.

The seismic reflection profile that crosses the central segment (USGS Line 1864, Fig. 6a) shows several buried slide events, similar to what occurs beneath the eastern segment (Fisher et al., 2005a). The surface of separation (sole) of the lower part of the central lobe appears to be $\sim 68 \mathrm{~m}$ (calculated as follows: $0.08 \mathrm{~s} \times \sim 1700 \mathrm{~m} / \mathrm{s} / 2$ ) deep beneath the zone of accumulation.

"Ventana" ROV dive V1503 of 12 October 1998 was made along a transect that extended from the western head scarp of the central segment approximately along the $250 \mathrm{~m}$ isobath near the head of the gullies at the top of the central head scarp (Fig. 5). Much of the dive was uneventful with the seafloor being generally composed of mud sediment. However, near the base of the steeper part of the head scarp, at $150 \mathrm{~m}$ water depth, rocks were found scattered about and many were of carbonate origin. About half way up the steep head scarp, in $\sim 125 \mathrm{~m}$ water depth, rocky outcrops occurred and gas was observed seeping out of the rocks. Rock samples collected at the top of the head scarp in $\sim 110 \mathrm{~m}$ of water were comprised of gravels and sands cemented with authigenic highmagnesium calcite, aragonite, and dolomite (Eichhubl et al., 2002; Fig. 5). In February 2005, "Tiburon" dive T816 was made up the steep western part of the central segment head scarp where a mud coated slope was observed.

\subsubsection{Western segment}

The western segment is the second largest of the three segments (Fig. 13). Its head scarp is not as well formed or as steep as the other two segments. The head wall appears to be composed of slumped material, not distinct head blocks such as observed in the central and eastern segments. In addition, the head scarp of this segment can be divided in two, a western and eastern scarp. The western scarp is larger in area $\left(\sim 0.32 \mathrm{~km}^{2}\right)$ than the eastern scarp $\left(\sim 0.08 \mathrm{~km}^{2}\right)$ with the western scarp having a steeper upper element. Both scarps have a median dip of $\sim 10.6^{\circ}$ with a fairly smooth debris apron at their bases. The eastern debris apron appears to spread over to the central segment abutting the minor scarp of the central segment head block. Within the western segment the smooth surfaced debris apron partially covers displaced material with weakly developed transverse ridges within the zone of depletion. Within the zone of accumulation two distinct displaced material flows exist with the one on the upper slope divided into a larger eastern $\left(\sim 4 \mathrm{~km}^{2}\right)$ and a smaller western $\left(\sim 3.8 \mathrm{~km}^{2}\right)$ section and the lower slope forming the major portion of the displaced material in the zone of accumulation (Fig. 11b), both have a generally smooth surface with no transverse ridges. The toe of the lobe is well developed with a distinct tip and does not extend as far out as the eastern lobe, but extends further down slope than the central lobe terminating at a depth of about $560 \mathrm{~m}$. Similar to the seafloor in front of the central lobe, an area of disturbed sediment exists, but is narrower in width then observed for the central lobe. A narrow secondary side failure is observed along the western edge of this segment, which lies within the zone of accumulation. It appears to represent one of the latest failures within this segment, which has been dated at about 6 to $8 \mathrm{ka}$ by Lee et al. (2004) and Fisher et al. (2005a).

Seismic reflection profiles across this lobe also indicate that many previous slide events have occurred and that as many as 5 different flows can be identified. This indicates that the western segment of Goleta slide is similar to the other segments and is comprised of buried slide masses (Fisher et al., 2005a). 
Three "Ventana" ROV dives (V1495, V1499 and V1500) were made in and around the head of the western segment during the October 1998 set of dives (Fig. 5). One dive, V1495, started at the western side head scarp of the western segment and traveled up slope to the top of the scarp where it turned north to transect most of the shelf at the head of the western segment. A sample of authigenic carbonate aragonite, an indicator of previous fluid flow or methane gas venting, was collected at the top of the central head scarp and at the top of the central segment head scarp. The other "Ventana" dive (V1499), along with dive V1500, traversed the western head scarp edge of the western segment starting at the western side of the central segment head scarp and traveled eastward along the edge of the shelf where they were terminated on the shelf. Authigenic aragonite carbonate was recovered along the shelf near the edge of the head scarp. Recent ROV dives using "Tiburon" (dives T814 and T815) indicated that the area is well covered with mud.

\subsection{Gaviota slide}

The Gaviota slide has been well described by Edwards et al. (1995) and Hampton et al. (1996), a feature they called the Gaviota mudflow. Using seismic reflection profiles these authors were able to well delineate the slide and found that several flow events have occurred. Lee and Edwards (1986) conducted a geotechnical study of the Gaviota mudflow using a series of core samples and an extensive set of static triaxial, cyclic triaxial and consolidation tests. The authors showed that moderate shaking from an earthquake could have caused the failure. The results were reinterpreted by Lee et al. (1992) to show that the density state of the sediment is low enough for the sediment to mobilize easily into a sediment flow. Such an observation may explain why the Gaviota failure has produced lobes suggestive of a sediment flow as opposed to a limited-deformation slump. We describe the slide here based on our interpretation of the multibeam bathymetry and for further information we refer the interested reader to Edwards et al. (1995) and Hampton et al. (1996).

The Gaviota slide is $1.65 \mathrm{~km}$ wide, $2.60 \mathrm{~km}$ long and covers an area of $3.78 \mathrm{~km}^{2}$ with its head located at $365 \mathrm{~m}$ water depth and its toe at $511 \mathrm{~m}$ (Fig. 14). It has a distinct head scarp of $\sim 8 \mathrm{~m}$ high with a slope angle of $16.7^{\circ}$ and a smooth surfaced zone of depletion. Several independent head blocks occur and one is a linear feature with well-formed secondary scarps, which is located on the eastern half of the slide. Other smaller and less intact blocks are found on the western half of the slide. The zone of accumulation is well defined and a distinct toe is present. The lower part of the zone of accumulation can be divided into two lobes separated by a narrow indentation and channel-like feature. The western lobe is hummocky and has transverse or compression ridges. The eastern lobe has some radial ridges and groves concentrated along its western margin. The overall slope angle of the slide from head scarp base to toe is $3^{\circ}$.

One "Tiburon" ROV dive (T153) was made at the head of Gaviota slide (Fig. 5). Although the seafloor in this area

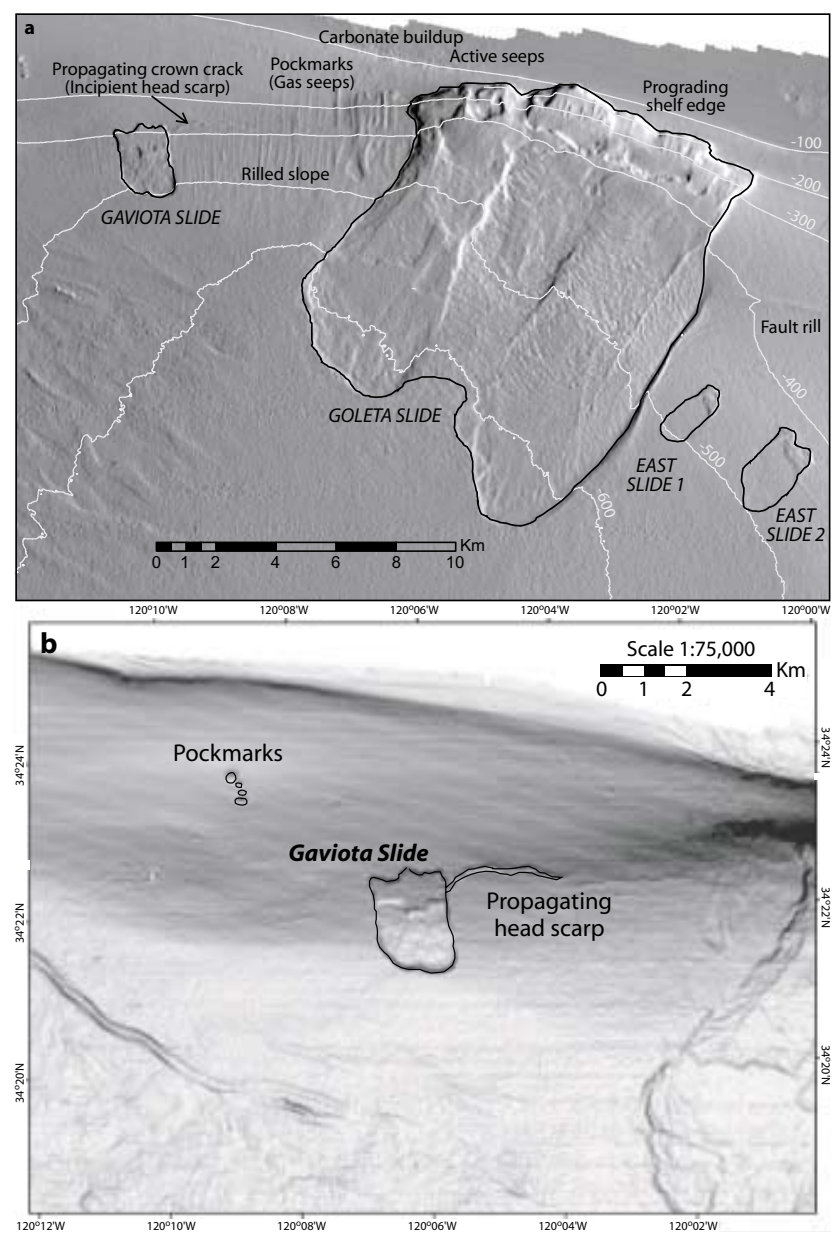

Fig. 14. Seafloor images of Goleta and Gaviota slides: (a) EM300 $30 \mathrm{kHz}$ multibeam slope shaded bathymetric image of the Gaviota slide, propagating head scarp, densely gullied slope, and Goleta bulge, (b) close up view of Gaviota slide.

was covered with mud and no fresh material indicative of recent failure was present, we did observe a fairly large area of black to gray bacterial mats in the zone of depletion (Fig. 8d), downslope of the base of the eastern part of the head scarp. The head scarp was of layered mud with a thin coating of flocculent material (Fig. 8c). Several vibra-cores were recovered from this slide using "Tiburon" ROV and one core taken during "Tiburon" dive T809 penetrated $\sim 50 \mathrm{~cm}$ of modern sediment to recover slide debris at depth (Fig. 8e). Lee et al. (2004) place the age of the slide at between 100 and 300 years ago based on a sediment cover of $50 \mathrm{~cm}$.

\subsection{Propagating head scarp - Goleta bulge}

Between the Gaviota and Goleta submarine landslides is a heavily gullied slope that extends from about $220 \mathrm{~m}$ water depth to $500 \mathrm{~m}$ deep. Concentration of the gullies are $\sim 8$ gullies $/ \mathrm{km}$ and represent the area containing the greatest amount of gullies in the Santa Barbara Basin region (Fig. 13b). The gullies are larger in size, better developed, and extend into 


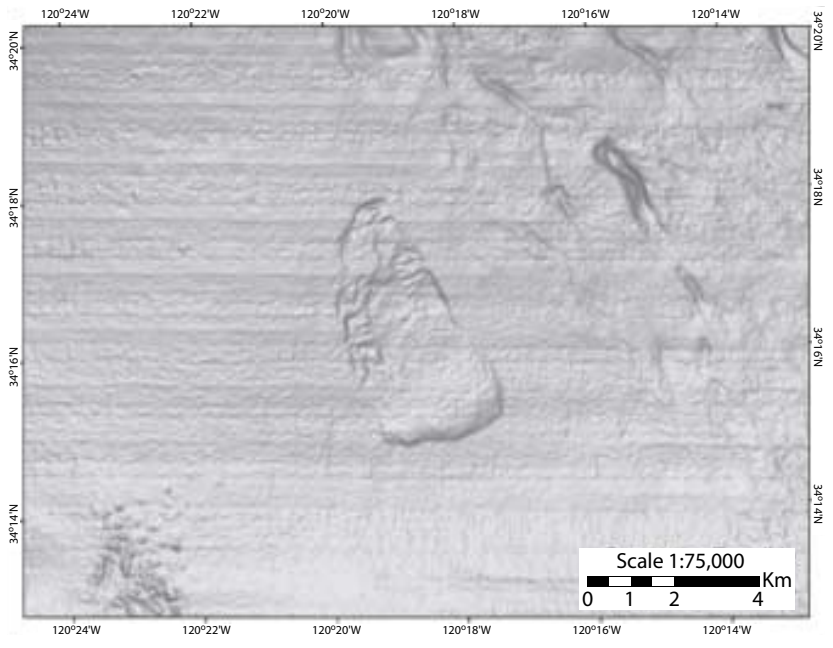

Fig. 15. EM $30030 \mathrm{kHz}$ multibeam slope shaded bathymetric image of Conception fan slide (a mudflow).

shallower water ( $\sim 220 \mathrm{~m}$ deep) in the eastern part of the slope than in the west. On the upper slope above the better developed gullies, an east-west trending zone of pockmarks exists, which lies below a zone of carbonate buildup on the continental shelf (14a). This is in the area of extensive gas venting offshore of Goleta Point (Quigley et al., 1999). Near the base of the slope where the gullies are best developed, a bulge of sediment, here called the Goleta bulge, has formed, perhaps the result of downslope creep (Fig. 13). This bulge lies immediately adjacent to, and west of, the western segment of the Goleta slide where apparently the most recent side flow occurred within the western segment.

From the upper eastern side head scarp of the Gaviota slide a trough or crack in the slope sediment at a water depth of $340 \mathrm{~m}$ trends east-west and can be mapped approximately $7 \mathrm{~km}$ (Fig. 13). This crack is $\sim 10 \mathrm{~m}$ wide and $\sim 2 \mathrm{~m}$ deep. It mainly cuts off the heads of the gullies and appears as a propagating head scarp to the Gaviota slide. The area of heavily gullied slope bounded at the top by the crack and at the bottom of the non-gullied slope, and from the eastern edge of Gaviota slide to the eastern limit of the crack, is $\sim 2.5 \mathrm{~km}$ wide and $\sim 6 \mathrm{~km}$ long covering an area of $15 \mathrm{~km}^{2}$. A faint expression of a crack at $400 \mathrm{~m}$ deep can be seen in the multibeam bathymetry to be extending eastward from this heavily gullied area to the Gaviota bulge, cutting the gullied slope in this area in half.

"Tiburon" ROV dives (T153 and T811) were made into the eastern propagating crack from the headward part of Gaviota slide (Fig. 5). We observed a distinct depression, sediment covered, with some bacterial mats located in the western terminus. No indication of recent movement or expansion of the crack such as freshly exposed mud layers or other subcrops that exist beneath the mud cover was detected.

\subsection{East slides 1 and 2}

Two small submarine slides exist on the slope east of the Goleta slide and are here called East slide 1 and East slide 2 (Fig. 12). East slide 1 is located approximately $1.75 \mathrm{~km}$ east of Goleta slide and is $0.95 \mathrm{~km}$ wide, $2.42 \mathrm{~km}$ long covering an area of $2.0 \mathrm{~km}^{2}$. The top of East slide 1 head scarp lies at $454 \mathrm{~m}$ depth and its toe at $510 \mathrm{~m}$. The angle of failure is $1.4^{\circ}$. It is a fairly linear failure with a well-defined zone of depletion and zone of accumulation. A single small head block exists in the zone of depletion and the head scarp is gentle $\left(8.1^{\circ}\right.$ inclination) and very subtle in the multibeam bathymetry. Centrally located along the eastern side head scarp of this slide, in the zone of depletion, a small arcuate trough or crack that is generally oriented in a northwestsoutheast direction, parallel to slope. In 2001 "Tiburon" dive T155 was made along the head of East slide 1 where a gentle mud covered scarp was found.

East slide 2 is the larger of the two east slides being $1.65 \mathrm{~m}$ wide, $2.85 \mathrm{~m}$ long, and covering an area of $4.15 \mathrm{~km}^{2}$, over twice the size of East slide 1 (Fig. 12). It has two distinct arcuate head scarps of generally equal dimensions with the tops of these heads at $422 \mathrm{~m}$ water depth and the combined toes are located at $500 \mathrm{~m}$. The zone of depletion is generally smooth surfaced with multiple head blocks, which are especially prominent at the base of the eastern arcuate head scarp. The toe of the slide is very subtle in bathymetry with the tip poorly developed. The angle of inclination is the same as East slide $1,1.4^{\circ}$. Similar to the Gaviota slide, the East slide 2 has a northwest-southeast oriented trough or crack that extends $\sim 1.4 \mathrm{~km}$ southeast from the eastern margin of the slide, starting at the boundary between the zone of depletion and the zone of accumulation.

\subsection{Conception fan slide}

The Conception fan slide lies on the southern margin of the Conception fan, a poorly developed submarine fan that spreads out into the center of the Santa Barbara Basin. Three submarine channels or small submarine canyons that just notch the distal edge of the continental shelf east of Point Conception are distributary channels and may still be supplying sediment to the fan (Figs. 4 and 15), although not as readily as during the Pleistocene (Fischer and Cherven, 1998). It is $\sim 2.3 \mathrm{~km}$ wide, $\sim 6 \mathrm{~km}$ long producing an area of failure $\sim 14 \mathrm{~km}^{2}$. The head of Conception fan is located in $\sim 380 \mathrm{~m}$ of water depth while its toe is in $\sim 440 \mathrm{~m}$. A head block with a distinct secondary scarp is located at the base of the head scrap, which rises $\sim 5 \mathrm{~m}$ and slopes $6^{\circ}$. The zone of depletion is hummocky with a series of transverse ridges or compression ridges concentrated along the sides of the slide. A well-developed toe exists with the tip rising $\sim 10 \mathrm{~m}$ above the surrounding seafloor. The overall angle of slope of the slide is $1.5^{\circ}$. 


\section{Structures and the mid-channel trend}

The Santa Barbara Basin is actively undergoing rotation and compression (Crouch, 1979; Kamerling and Luyendyk, 1979, 1985; Jackson and Molnar, 1990; Crouch and Suppe, 1993; Nicholson et al., 1994). This tectonic activity has produced several major thrust faults and folds that generally trend east-west and are primarily concentrated along the northern margin of the basin (Fig. 8a). The folds mapped in the subsurface of the margin beneath the shelf are comprised of the Molina and Conception anticlinal trends, Gaviota and Government Point synclinal trends (Luyendyk, 1998), with the anticlines being hydrocarbon traps and the main targets for petroleum extraction. The Pitas Point-Ventura fault controls the shelf break in this area and extends onland to the east connecting with the Oak Ridge anticlinorium and fault system (Greene et al., 1978; Fisher et al., 2005b).

The Mid-Channel Trend is an anticlinorium bounded on either side by faults (Fig. 2b). The apex of the structure is composed of hummocky carbonate buildup resulting from extensive methane gas venting. Pockmarks and carbonatecemented sediment have been observed using MBARI's ROV "Ventana" (dives V1501 and V1502). This structure plunges to the west and dips beneath the Goleta slide with the northern side of the western distal end of the anticline being marked by a well-established, linear gully that overlies the trace of the Oak Ridge Thrust fault.

\section{Volume estimation of Goleta slide}

Metric information extracted from the EM 300 bathymetric data were used to determine volume and to model tsunamigenic potential of Goleta slide, with the volume of material translated downslope being of particular importance. Precise volumetric measurements in this case are somewhat problematic since there is no bathymetry for the previously existing slope surface, although seismic reflection profiles are used to confirm thickness estimate of deposits along some lobes. Volume calculations using a surface subtraction method, and estimation assuming a half-ellipsoid shape (after Beyer, 1987) were applied.

To determine the volume of material that most recently failed, which produced the modern day morphology of the Goleta slide, we treat the three mapped segments (western, central, and eastern) as independent failures. We use nomenclature for landslide components that were developed for terrestrial landslides by Varnes (1978) and the International Association of Engineering Geology (IAEG) Commission on Landslides (1976). A computer generated oblique view of the Goleta slide, viewed toward the north, with many of the landslide features labeled after these authors are shown in Fig. 11a.

In all cases the amount of material deposited in the areas of accumulation is less than the removed material from the zone of depletion. Good thickness estimates were not possible on most of the smaller slides in the region and this could

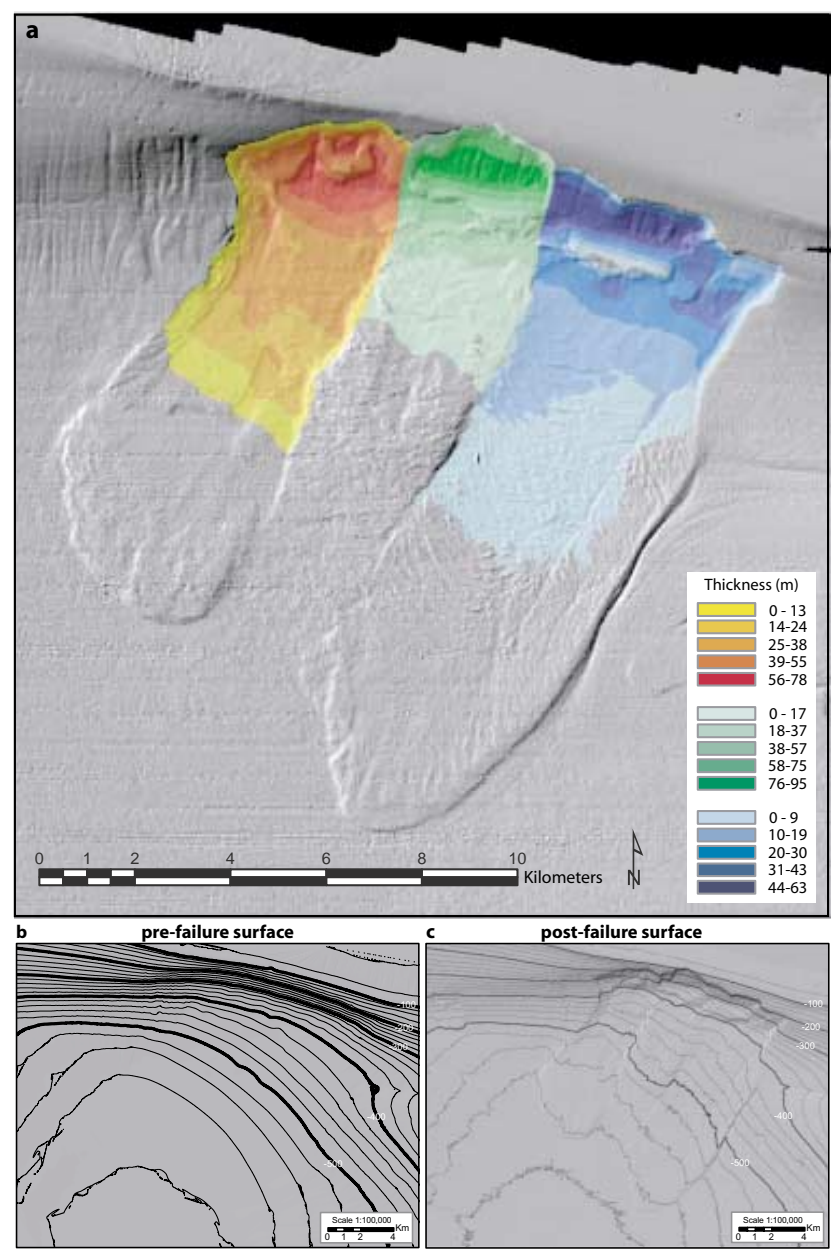

Fig. 16. Maps showing thickness and bathymetric contours of the Goleta slide complex: (a) isopac map of surface changes in the Goleta slide complex, (b) assumed bathymetry prior to recent failures, (c) bathymetric contours after failure; differences between (a) and (b) bathymetry used to calculate volumes of depletion (excavation) and accumulation (deposition).

be the reason for the disparities. Also, there is a chance that at least the three most recent individual lobes of Goleta slide probably failed at different times, therefore, we have calculated displaced volumes for each of the three individual lobes or segments as $0.592 \mathrm{~km}^{3}$ of material moved in the western lobe, $0.434 \mathrm{~km}^{3}$ moved in the central lobe, and $0.480 \mathrm{~km}^{3}$ moved in the eastern lobe producing a total of $1.506 \mathrm{~km}^{3}$ of displaced material (Figs. 16a, b).

\section{Discussion}

The Santa Barbara Basin exhibits considerable mass wasting features in the form of gullies and landslides (Fig. 4). The most dominant seafloor feature in the region is the Goleta landslide, a large ( $134 \mathrm{~km}^{2}$ in area) complex compound landslide that is divided into three distinct individual surface segments (Fig. 11). Other smaller landslides exist in the general 
vicinity of the Goleta slide and all but one, are concentrated along the northern margin of the basin. A single, fairly large slide exists at the southern margin of the Conception fan, a depositional slope and upper sill (Conception sill) that marks the western flank of the basin. Here, sediment appears to have accumulated from dispersal along three different distributary channels.

Based on our interpretations of the detailed EM 300 $30 \mathrm{kHz}$ digital multibeam swath bathymetry and backscatter data, seismic reflection profiles, and observations and sampling from ROVs, along with a literature review, we conclude that submarine landslides within the Santa Barbara Basin are probably caused from a combination of mechanisms and that a fairly lengthy historical record of mass movement exists that suggests a periodicity of failures on the order of millennia. We estimated the volume of material evacuated from the northern slope area and modeled the probable resulting tsunamis that may have occurred from rapid, cohesive failures.

\subsection{Types of failure}

The multibeam bathymetry indicates that many different types of slope failures and mass movements have occurred along the flanks of the Santa Barbara Basin. These failures range from possible sediment creep as illustrated in the Goleta bulge (Fig. 13), to mud flows such as illustrated by Gaviota slide (Figs. 13 and 14), to simple thin sediment flows as exhibited by East slides 1 and 2 (Fig. 12), to the more complex compound landslide of the Goleta slide that includes mud flows and rotational slumps (Fig. 11). The characteristic of many of these slides and the adjacent slope morphologies such as seen in the propagating head scarps or crown cracks of Gaviota slide (Fig. 13) and East slides 1 and 2 (Figs. 4 and 12) suggest that these slides may initially fail at mid slope resulting in downslope sediment flow and headward erosion through retrogressive slumping. The more cohesive mass movements appear to occur near the top of the slope as illustrated in the slump blocks at the base of the Goleta slide's head scarp and my be the failures that have the highest likelihood of generating a significant tsunami.

\subsection{Mechanisms of failures}

Our study suggests that several different mechanisms may be responsible for the mass movement phenomena exhibited in the Santa Barbara Basin. Although it is not possible for us to single out one mechanism responsible for the landslides, we speculate here on the potential of four major mechanisms we feel may be the primary stimulants for mass wasting in the Santa Barbara region (Fig. 17). These include sediment accumulation, fluid flow, tectonic over steepening, and seismic incitement (earthquakes). Specifically the northern slope of the basin is the steepest in the region, is cut by many faults, is undergoing uplift and compression, and has an extensive amount of fluid flow and gas venting.

\subsubsection{Sediment accumulation}

The highest concentrations of seafloor failures in the Santa Barbara Basin lie along the northern margin of the basin and are indicative of the active sedimentary processes there, as well as fluid flow, and tectonic processes active in the region. Much of the sediment that enters the Santa Barbara Channel region is from the erosion of coastal cliffs and within the Transverse Ranges, with the resultant detritus eroded inland being carried to the sea by the Santa Clara and Ventura rivers, the major fluvial sources of the region. Fine-grained sedimentary deposits that enter the channel from the rivers during flood periods are generally transported to the west along the coastline and settle out of the water column in the vicinity of Goleta Point (Fig. 10; Thornton, 1984). A muddy prograding shelf edge exists all along the shelf here from Goleta to Gaviota (Figs. 4 and 10) and suggests a major depocenter of fine-grained sediment that may become unstable along the shelf break. Along this shelf break Fisher et al. (2005a) have mapped what appears as a shelf edge delta deposit from the interpretation of seismic reflection profiles.

\subsubsection{Fluid flow}

Hydrocarbon reservoirs in the Santa Barbara Basin have been leaking fluids and gas for the past 60000 of years (Kennett et al., 2000), which produced distinct seafloor morphologies such as active gas vents, pockmarks, tar-flows, and carbonate mounds and pavement (Figs. 2, 8a, b, c, and 9). The Neogene Santa Barbara Basin is filled with $8-10 \mathrm{~km}$ of Upper Jurassic to Holocene sedimentary sequences of sand-, silt-, and mudstone (Dibblee, 1982a, b; Yeats, 1983; Dickinson et al., 1987; Kennedy et al., 1987) and has been a major offshore petroleum production providence since the 1960s. The basin sits within the transform plate boundary that separates the North American Plate from the Pacific Plate and is presently being subjected to transpression. The transpressive effect results in the shortening of the basin through compression forming several distinct folds (anticlines) and thrust faults. Much of the morphology formed by gas and fluid seeps exhibit trends that are aligned with these structures (Fig. 9) and many consist of carbonate and tar mounds and tar flows (Fig. 8b; Eichhubl et al., 2002). Although no authigenic carbonates were recovered during MBARI's ROV "Ventana" dives V1492 and V1506 along the south branch of the Santa Ynez fault, we suspect that carbonate mounds do exist based on the form and linearity of mounds along the projected western extent of the fault (Fig. 7) indicating that faults focus or control fluid flow in the region as shown by the deposition of carbonates and gas seeps along fault trends. Examples of such leaking faults is exhibited along the Coal Oil Point shelf edge where the trend of the Pitas Point fault has been mapped and exhibits curtains of gas venting along parallel lines to the fault trend. In addition, the east-west oriented gully just off the Goleta slide lies over the trace of the Oak Ridge Thrust fault and exhibits possible past fluid flow or focused sediment transport as indicated by the bedforms 

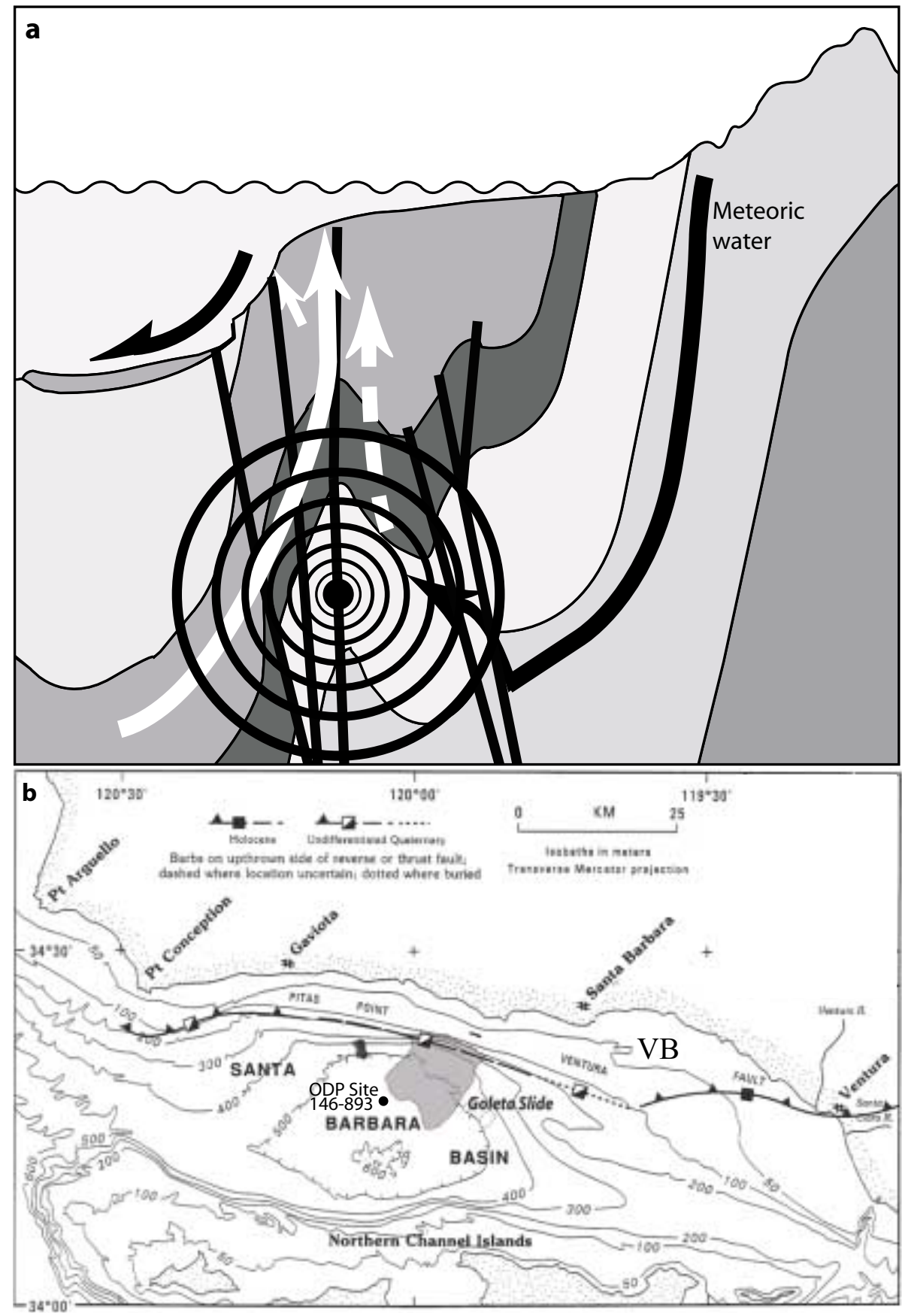

Fig. 17. Mechanisms of failures: (a) diagram showing postulated fluid flow directions along faults, folds indicating uplift, and earthquakes, all which play a role in seafloor failure, and (b) location of major faults that direct fluids to the seafloor and along which faults can rupture during earthquakes. Modified after Eichhubl et al. (2002).

that lie at the mouth of this feature near the base of the western lobe of the Goleta slide (Fig. 12).

\subsubsection{Tectonic oversteepening}

Compression is elevating the northern flank of the Santa Barbara Basin and overturning the slope here. Several thrust faults exist beneath the shelf, at the shelf break, and along the middle to upper slope (Fig. 2a) along which uplift (thrusting) occurs leading to the destabilization of the slope sediment.

Folding along the western part of the Mid-Channel trend anticlinorium (Fig. 2b) and fluid escape along the faults controlling the uplift of this horst-like feature may be a major cause of slope failure in the primary area of destabilization along the northern flank of the Santa Barbara Basin. The westward plunging axis of this feature trends beneath the 
central part of the Goleta slide where we suspect initial failure may have occurred.

\subsubsection{Seismic excitation (earthquakes)}

The Santa Barbara Channel lies within an active earthquake zone (the San Andreas transform fault zone) with many active faults that have the potential to rupture during earthquakes (Toppozada et al., 2002; Fig. 3). Earthquakes can stimulate failures on the actively steepening slope of the northern Santa Barbara Channel, especially during times when sediment accumulation approaches its angle of repose. Past earthquakes, both onland and offshore, may have been the trigger for many of the seafloor failures yet no conclusive evidence has been presented to confirm a relationship between mass movement and seismicity. However, the tsunamis reported in 1812 (Senon, 1813; Toppozada et al., 2000) may have resulted from a seafloor failure either associated with the Gaviota slide or one of the lobes of the Goleta slide.

\subsection{Age and periodicity of mass movements}

Dating of submarine slides in the Santa Barbara Channel is difficult although attempts have been made (Lee et al., 2004; Greene et al., 2004) with an approximate age of ca. 300 years given to the Gaviota slide (Lee et al., 2004) based on geotechnical data and an age of approximately ca. 8000 to ca. 10000 years given for the older (central and eastern) segments of the Goleta slide based on sediment accumulation rates of Thornton (1984), Lee et al. (2004) and Fisher et al. (2005a) applied to seismic reflection sediment thickness (Greene et al., 2004). In most cases geomorphology, or the sharpness of a mass movement feature such as a head scarp, is used to estimate the age of a feature in relation to other similar features in the area. For example, a sharp, well-defined feature identified in high-resolution multibeam bathymetric imagery is interpreted as youthful whereas a more subtle or less welldefined feature may be interpreted as mature. Placing an age to these features is generally more difficult without additional information such as sediment cover, if any, and known sediment accumulation rates. In situ observations indicated that all slides are heavily draped with mud and a core taken in Gaviota slide shows at least $50 \mathrm{~cm}$ of mud draping landslide debris (Fig. 8e). In addition, we have noted that the presence of gullies in areas of potential incipient slides, such as the upper slope between the Gaviota and Goleta slides, and on head scarps, such as on the head scarp of the central segment of the Goleta slide. Since these slides are located in an active hydrocarbon seep area we interpret one major mechanism of seafloor failure here to be from fluid flow that occurs prior and after a mass movement event. As an indicator of age, gullying may be a precursor to failure in areas of heavy fluid flow. Also, gullies may be an indicator of older age in landslide scars because they show the passage of time during which the scar has been eroded by gulling. Therefore, we use geomorphic evidence such as gullies to assign a relative geomorphic age to a slide.

Based on geomorphic relationship we estimate the relative ages of the various segments of the Gaviota slide to be the following: 1) middle segment is oldest based on welldeveloped gullies in its head and apparent erosional lobe sides; 2) the eastern segment is intermediate in age between the west and east segments based on buried head blocks and apparent sharper morphology than observed in the central segment; 3) west segment appears the youngest as it has what we interpret to have the sharpest morphology of the three segments.

For the Goleta slide we calculated that about $64 \mathrm{~m}$ of sediment was dammed behind the block based on a measured two-way travel time in the sediment pond of $0.075 \mathrm{~s}$ and an assumed velocity of $\sim 1680 \mathrm{~m} / \mathrm{s}$ through the sediment. Using a sedimentation rate of $1.73 \mathrm{~m} / \mathrm{Ka}$ to $2.5 \mathrm{~m} / \mathrm{Ka}$, the range of sedimentation rates determined by Thornton (1984), Edwards et al. (1995), and Eichhubl et al. (2002) for the midto lower shelf areas of the western Santa Barbara Basin, a time for deposition would range from $37 \mathrm{Ka}$ to $25.6 \mathrm{Ka}$. Therefore, if the sedimentation rates are correct and that the ponded sediments represent nothing but normal sedimentation devoid of sloughing or debris flow down the slope, the maximum age of when the block came to rest in its present position is 37-25.6 Ka. However, given the tectonic dynamics of the area and the instability of the slope in this part of the Santa Barbara Basin the likelihood of deposits derived from mass movement filling the depression behind the slump block is high, thus reducing the age estimate of the block slumping event considerably.

Also, based on continuous marine seismic reflection profile stratigraphy and correlation with well hole stratigraphy obtained from ODP Drill Site 149, Hole 893 Fisher et al. (2005a) place an age of ca. 200000 years for the first failure of the Goleta slide to have occurred. Many of the buried slide fronts have deformed the basin sediments along a frontal thrust surface with spill over lobes continuing out along the basin floor as runout lenses (Fisher et al., 2005a).

Based on our geomorphic analyses Gaviota bulge appears unstable and may be creeping down hill as suggested by its extensional-like lobe at the base of the gullies and may likely be prone to failure sometime in the future. It lies on the western edge of the western segment of the Goleta slide, the apparent last segment of the Goleta slide to have failed. In addition, the young Gaviota slide lies to the west of the bulge and appears to be connected to this feature by a propagating head crack (Fig. 13). The upper slope here is heavily gullied with pockmarks along the upper slope and authigenic carbonate deposits on the shelf, all indicators of past fluid seeps (Eichhubl et al., 2000).

\section{Tsunami modeling}

We study landslide motion, as well as tsunami generation, propagation, and inundation in this section, based on the 
foregoing geological data and interpretations. Our approach to modeling combines our marine geology data (i.e., the geological context) with state of the art landslide and tsunami simulations. The geological context addresses questions, such as: Where are underwater landslides most likely to occur? What are typical dimensions of such underwater landslides? The landslide model addresses questions, such as: How quickly does a landslide accelerate from rest? Where will the deposit come to rest? With answers to these questions, however uncertain or imprecise, we can simulate wellposed tsunami scenarios that are a direct consequence of the geological context and landslide model results. The tsunami modeling is therefore dependent on the geological context and the landslide model. Previous authors have modeled potential tsunami generation in the location of the Goleta slide based on models derived from analyses of the 1998 Papua New Guinea landslide tsunami (Tappin et al., 1999, 2001; Borrero et al., 2001). In general, landslide tsunami amplitudes can vary over more than six orders of magnitude depending on the geological context and the landslide features (Watts et al., 2003; Watts, 2004a, b).

\subsection{Landslide motion analyses}

Momentum and constitutive equations that describe landslide shape and motion over time can be relatively involved (Imran et al., 2001; Iverson and Denlinger, 2001). In contrast, the center of mass motion of dense landslides can be approximated by simple equations of motion, whether hot or cold, wet or dry (Savage and Hutter, 1989; Watts, 1997; Walder et al., 2003; Watts and Waythomas, 2004). We note that the landslides described above exhibit significant deformation about the center of mass. However, it is the center of mass motion itself that is the primary source of tsunami generation (Watts and Grilli, 2003), with deformation about the center of mass being a second order tsunami generation effect (Watts, 2004c). In this work, we reproduce both 1) the landslide center of mass motion, and 2) the landslide deformation about the center of mass. We sketch our model of landslide center of mass motion based on the model described more fully in Waythomas et al. (2005) ${ }^{1}$.

We discretize a two-dimensional transect of the actual slope into piecewise linear segments, and consider a landslide moving down a given planar segment at angle $\theta$ to horizontal by extracting points from a grid file. An equation of motion for instantaneous velocity $u(t)$ along each planar segment has the form

$$
\frac{d u}{d t} \approx \frac{B}{A}-\frac{C}{A} u^{2}
$$

where the coefficients $A \equiv\left(\rho_{b}+C_{m} \rho_{o}\right)$, $B \equiv\left(\rho_{b}-\rho_{o}\right) g\left(\sin \theta-C_{n} \cos \theta\right), \quad$ and $\quad C \equiv \rho_{o} C_{d} / 2 L$ are slowly varying functions of time (Watts, 1997). In these three coefficients, one finds that $\rho_{b}(t)$ denotes the

\footnotetext{
${ }^{1}$ Waythomas, C. F., Watts, P., and Walder, J. S.: Tsunami generation by cold volcanic grain flows: An example from Augustine volcano, Alaska, in preparation, 2005.
}

instantaneous bulk density, $\rho_{o}$ denotes the ambient fluid density, $C_{m}$ denotes the added mass coefficient, $g$ denotes the acceleration of gravity, $C_{n}(t)$ denotes the instantaneous Coulomb friction coefficient, $C_{d}$ denotes the total drag coefficient, and $L(t)$ denotes the instantaneous landslide length. The three center of mass motion coefficients $0.9<C_{m} \leq 1.8$, $0.01 \leq C_{n} \leq 0.2$, and $0.7 \leq C_{d}<2.1$ can be parameters in a sensitivity analysis, varying over the full ranges given here (Watts, 1998, 2000; Grilli and Watts, 1999; Grilli et al., 2002; Enet et al., 2003; Brodsky et al., 2003). Landslide center of mass motion is typically insensitive to reasonable variations in the added mass coefficient $C_{m}$ and the total drag coefficient $C_{d}$.

We solve for the velocity $u(t)$ of a landslide over time steps $\Delta t=t-t_{i}$ using the differential equation shown above. The landslide velocity $u(t)$ typically starts with $u_{i}=0$ at $t_{i}=0$ on a relatively steep slope and is updated at each time step $\Delta t$ until it comes to rest. We solve for landslide position $s(t)$ along the incline by integrating the velocity $u(t)$ numerically over time. Some features of landslide deformation can be parameterized in terms of the center of mass motion, including the instantaneous landslide length (Watts and Grilli, 2003). This allows us to include landslide deformation in the model of landslide motion. The landslide thickness is found from conservation of mass, but is confirmed through measurements based on seismic stratigraphy and volume estimates by reconstruction of pre-slide bathymetry (Fig. 16b, c). In this model, the customary distinctions of underwater landslides are determined by the instantaneous Coulomb friction coefficient $C_{n}(t)$, where slumps would presumably possess higher friction coefficients (Watts et al., 2003).

We use the landslide model to solve for the initial acceleration $a_{o}$, and the runout distance $r_{u}$, both quantities evaluated for the center of mass. In what follows, we use the runout distance $r_{u}$ to calculate a reasonable mean Coulomb friction coefficient $C_{n}$, because we are modeling historical events with a known deposit location. We then use the landslide initial acceleration $a_{o}$ to construct the tsunami source, because landslide initial acceleration is responsible for almost all tsunami generation (Watts, 1998), as opposed to landslide deformation about the center of mass, which can be neglected (Watts, 2004c). To do this, we assume a single mass failure event of relatively good initial coherence for the purposes of tsunami generation. If this were not true, then the deposit would consist of thin layers of turbidites. We took bathymetric transects down the middle of each landslide lobe with at least 25 piecewise linear segments. Using typical values found from similar model runs, we adopt the following reasonable values: $\rho_{b}=1900, \rho_{o}=1025, C_{m}=1.17$, and $C_{d}=1.44$. We follow Watts and Grilli (2003) and further assume 1), that landslide deformation increases center of mass acceleration by $40 \%, 2)$, that landslide length increases by $35 \%$ of the distance traveled by the center of mass, and 3), that the landslide nose increases its distance from the center of mass by $16 \%$ of the distance traveled by the center of mass. These assumptions allow us to reproduce the elongation and final deposit thickness of each landslide. The inputs and outputs of the 
Table 1. Landslide motion parameters.

The inputs for the landslide model are, in descending order, the initial landslide length $L_{o}$, the initial landslide thickness $T_{o}$, and the mean initial landslide depth $d$. The outputs from the landslide model are the landslide initial acceleration $a_{o}$, the runout distance from headwall to deposit nose $r_{u}$, the Coulomb friction coefficient $C_{n}$, the maximum landslide velocity $U_{\max }$, the total duration of landslide motion $\Delta t$, and the final landslide thickness $T_{f}$.

\begin{tabular}{lccc}
\hline Quantities & Western & Central & Eastern \\
\hline$L_{o}(\mathrm{~m})$ & 6330 & 3100 & 4050 \\
$T_{o}(\mathrm{~m})$ & 39 & 68 & 48 \\
$d(\mathrm{~m})$ & 455 & 320 & 260 \\
$a_{o}\left(\mathrm{~m} / \mathrm{s}^{2}\right)$ & 0.337 & 0.510 & 0.334 \\
$r_{u}(\mathrm{~m})$ & 12616 & 10873 & 13735 \\
$C_{n}$ & 0.012 & 0.019 & 0.017 \\
$U_{\max }(\mathrm{m} / \mathrm{s})$ & 22.8 & 21.6 & 28.0 \\
$\Delta t(\mathrm{~s})$ & 896 & 785 & 822 \\
$T_{f}(\mathrm{~m})$ & 24.8 & 32.1 & 23.2 \\
\hline
\end{tabular}

landslide model for all three landslides are summarized in Table 1.

The initial landslide length $L_{o}$ is taken from the geological data above (also see Figs. 6 and 16). The initial landslide thickness $T_{o}$ is calculated from the initial landslide length, the estimated landslide volume, and the headwall width and confirmed through the observation of seismic reflection profiles (Fig. 6). The mean initial landslide depth $d$ follows from the assumed geometry of the initial landslide mass. The Coulomb friction coefficient is a proxy for basal shear stress regardless of landslide rheology during motion. The Coulomb friction coefficient $C_{n}$ is chosen such that we reproduce the observed runout distance from headwall to deposit nose $r_{u}$ by trial and error. There is an apparent change in landslide basal friction from western segment to eastern segment according to our results, although we do not know if it is significant. We also compute the landslide initial acceleration $a_{o}$, the maximum landslide velocity $U_{\max }$, the total duration of landslide motion $\Delta t$, and the final landslide thickness $T_{f}$ by examining different aspects of the motion data. The total duration of landslide motion includes the duration of landslide acceleration $t_{o}$ as well as all subsequent motion until the landslide comes to rest. The final landslide thicknesses are close to the observed values of maximum deposit thickness. We have therefore captured landslide deformation.

\subsection{Approximate tsunami sources}

We calculated approximate tsunami sources for the Western segment of the Goleta landslide complex, as it may be the latest failure within the complex, using the landslide volumes presented above and version 1.2 of the Tsunami Open and Progressive Initial Conditions System (TOPICS). Although the Eastern and Central segments were modeled and show similar size tsunamis, we do not include them here as they
Table 2. Landslide tsunami source parameters.

The inputs for TOPICS are, in descending order, the longitude of the initial landslide center $x_{o}$, the latitude of the initial landslide center $y_{o}$, the specific density $\gamma$, the initial landslide length $b$, the maximum initial landslide thickness $T$, the maximum landslide width $w$, the mean initial landslide depth $d$, and the mean initial incline angle $\theta$. The outputs from TOPICS are the landslide initial acceleration $a_{o}$, the characteristic time of landslide motion $t_{o}$, the characteristic tsunami wavelength $\lambda_{o}$, and the characteristic tsunami amplitude $\eta_{o}$ from the depression wave at time $t=t_{o}$.

\begin{tabular}{lccc}
\hline Quantities & Western & Central & Eastern \\
\hline$x_{o}$ (longitude) & $-119.944^{\circ}$ & $-119.919^{\circ}$ & $-119.896^{\circ}$ \\
$y_{o}$ (latitude) & $34.460^{\circ}$ & $34.417^{\circ}$ & $34.392^{\circ}$ \\
$\gamma$ & 1.85 & 1.85 & 1.85 \\
$b(\mathrm{~m})$ & 6330 & 3100 & 4050 \\
$T(\mathrm{~m})$ & 39 & 68 & 48 \\
$w(\mathrm{~m})$ & 3600 & 3100 & 3700 \\
$d(\mathrm{~m})$ & 455 & 320 & 260 \\
$\theta($ degrees $)$ & $6.6^{\circ}$ & $10.0^{\circ}$ & $6.5^{\circ}$ \\
$a_{o}\left(\mathrm{~m} / \mathrm{s}^{2}\right)$ & 0.337 & 0.510 & 0.334 \\
$t_{o}(\mathrm{~s})$ & 290 & 165 & 233 \\
$\lambda_{o}(\mathrm{~km})$ & 19.4 & 9.3 & 11.8 \\
$\eta_{o}(\mathrm{~m})$ & -7.6 & -22.3 & -16.9 \\
\hline
\end{tabular}

will be included in a future paper. We also study a prospective tsunami source from failure of the Goleta Bulge. TOPICS is an approximate model that provides initial free surface elevations and water velocities for tsunami propagation and inundation simulations. This is called a tsunami source. The characteristic time of landslide motion $t_{o}$ is also the duration of tsunami generation (Watts, 1998, 2000). Consequently, TOPICS provides the tsunami source at time $t=t_{o}$, as if the 3-D simulation results of Grilli and Watts (2001) or Grilli et al. (2002) were being transferred directly to a tsunami propagation model. It is the proxy use of the 3-D numerical simulations that provides state of the art tsunami sources, with the substantial benefit of not having to run the 3-D model for each case study. With the direct use of 3-D model results within TOPICS, there is no longer any conversion of 2-D to 3 -D shapes necessary. TOPICS is a free tsunami community model in extensive use around the world.

Our tsunami source inputs and outputs are summarized in Table 2 for all three landslide segments, where some values are identical to those found in Table 1. The landslide width was determined from the existing width of the headwall. The maximum landslide thickness perpendicular to the slope varied depending on whether we considered the deposit thickness or block thickness. We chose conservative values for all landslide dimensions because there is considerable impact of volume errors on tsunami amplitude. Similarly, we assumed a sediment density that is typical for many types of marine sediment. We matched the landslide acceleration in TOPICS with that of the landslide model by using an effective slope angle, rather than the actual slope angle, although the 


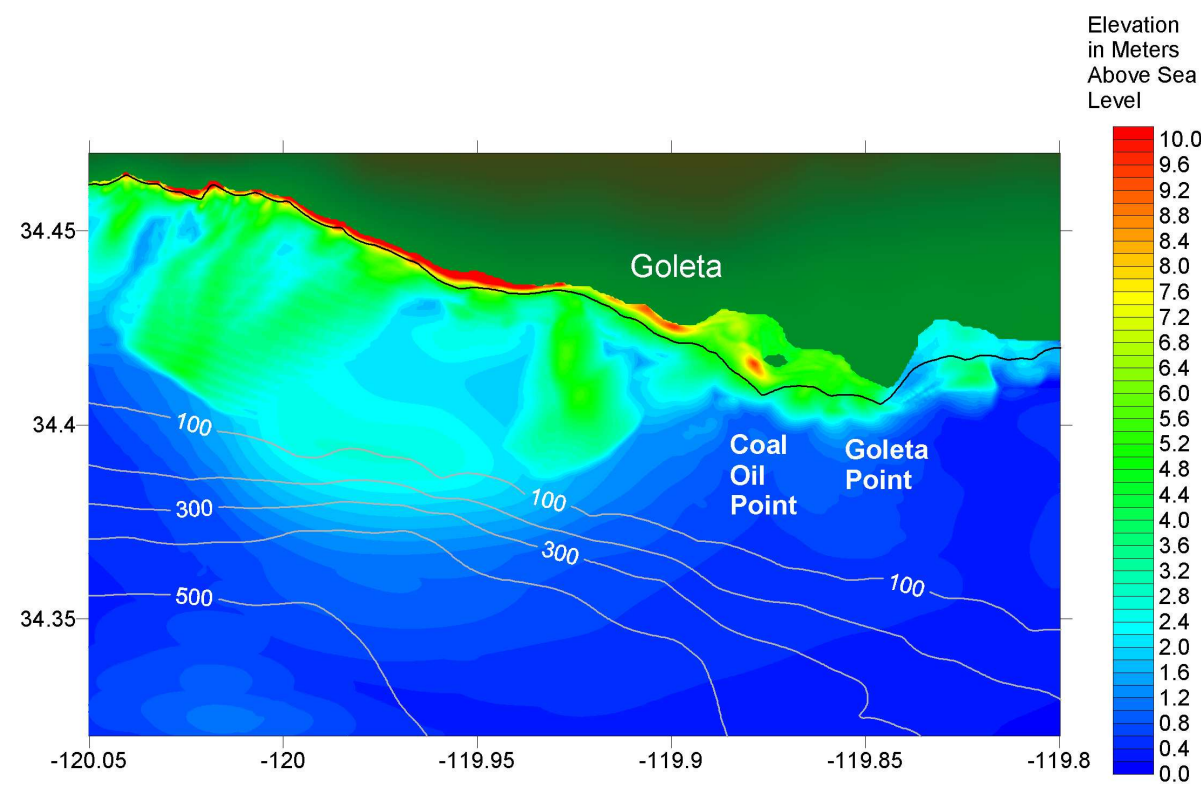

Fig. 18. Map of maximum tsunami amplitudes at any time during the numerical simulation of the tsunami generated by the Western segment of the Goleta Slide.

differences in slope were small. The duration of landslide acceleration provides the characteristic time $t=t_{o}$ in Table 1 , which is also the tsunami period, as well as the time at which TOPICS provides the tsunami initial condition for tsunami propagation and inundation calculations.

\subsection{Tsunami propagation and inundation simulation}

Geowave is a long wave propagation model based on the Boussinesq approximation of wave dynamics developed for the public domain software FUNWAVE (Wei et al., 1995; Wei and Kirby, 1995). The Boussinesq approximation expands linear long wave theory into nonlinear and dispersive regimes. The wave propagation model is fully nonlinear and able to simulate a wide range of wavelengths not limited to long waves (Wei et al., 1995). FUNWAVE is designed to model the physics of breaking waves and runup (Chen et al., 2000; Kennedy et al., 2000). Geowave takes the tsunami source from TOPICS and inputs this as an initial condition into FUNWAVE at time $t_{o}$ after the landslide begins accelerating. This is the only time at which Geowave can transfer the surface elevation from TOPICS to FUNWAVE, and this time is fixed by landslide dynamics that are specific to each event. Geowave has been extensively validated through tsunami case studies (e.g., Watts et al., 2003). Geowave has almost always reproduced tsunami observations the first time a simulation is performed, and it has usually reproduced all tsunami observations. Geowave is also available for free as a tsunami community model, and is in use around the world.

Our simulation of the tsunami generated by the Western segment of the Goleta slide complex shows a distinct impact on the local coastline. Hypothetical failure of the Goleta Bulge is also simulated, as is the worst-case scenario, which has all three segments of the Goleta complex slid- ing simultaneously. This last simulation highlights certain distinctions from our simulations for each individual segment. Geowave and FUNWAVE are depth integrated water wave models valid for all wavelength water waves. These codes do not produce the same results for near shore landslide generated tsunamis as non-linear shallow water wave (NSWW) models. NSWW models typically break down for short wavelength waves, as shown by Lynett and Liu (2002) and found by Watts et al. (2003), especially for landslide tsunamis shoaling in shallow water. In response to the need to model short wavelength waves, our model runs on a $50 \mathrm{~m}$ grid with a $0.2 \mathrm{~s}$ time step, providing unprecedented spatial and temporal resolution of tsunami runup, combined with the accuracy of one of the most sophisticated water wave propagation and inundation codes available.

\subsubsection{Tsunami impact from individual lobe failures}

Our model of the tsunami generated by the Western segment of the Goleta Slide (Fig. 18) predicts waves sent directly towards Coal Oil Point, resulting in runup that reaches $10 \mathrm{~m}$ above sea level and lateral inundation of nearly $2180 \mathrm{~m}$ on the western side of the point. Onshore currents exceed $6.0 \mathrm{~m} / \mathrm{s}$ northeast of Coal Oil Point, and offshore currents in the same region can reach $11.9 \mathrm{~m} / \mathrm{s}$. Three distinct bands of onshore wave breaking are found in this area, with their eastern end around Goleta Point. Wave breaking is widespread throughout the inundated areas as well as just offshore of these same areas. West of Coal Oil Point, tsunami runup fluctuates between $5 \mathrm{~m}$ and $10 \mathrm{~m}$, influenced by the nearshore bathymetry. Offshore currents are reduced, but still strong, reaching nearly $7.0 \mathrm{~m} / \mathrm{s}$ around $119^{\circ} 57^{\prime} 23^{\prime \prime} \mathrm{W}$ Longitude, and wave breaking occurs along the entire coast, with the 
extent of wave breaking exhibiting a direct correlation to the strength of the offshore current.

The modeled tsunamis that are generated by the Central and Eastern segments of the Goleta Slide are largely similar to the Western segment, with peaks and troughs in runup occurring in roughly the same locations along the coast. The peaks appear to be controlled by offshore bathymetry and the shape of the shoreline. The Central and Eastern tsunamis would have originated in shallower water than the Western tsunami, and the Central lobe's tsunami wavelength would have been the shortest of the three, causing more wave energy to be directed toward the shore. The tsunami caused by the Western segment of the Goleta slide complex shares many features in common with the tsunamis predicted from the Eastern and Central segments. Because it originates further west of Coal Oil Point, the Western segment tsunami has a limited effect on the eastern shore of Coal Oil Point and on Goleta Point relative to the other two segments.

\subsubsection{The Goleta Bulge}

The Goleta Bulge, adjacent to and just west of the Western segment of the Goleta slide, was identified as a potential source of future landslide activity, so it was modeled as a potential landslide tsunami scenario. The bulge turns out to have significantly smaller dimensions than the other segments $(2310 \mathrm{~m}$ wide, $3000 \mathrm{~m}$ long, $35 \mathrm{~m}$ thick, and at a shallower mean angle of 4.76 degrees). These facts result in a much smaller tsunami than the three extant slides. The resulting tsunami produces maximum runup of $5.7 \mathrm{~m}$ at $120^{\circ} 01^{\prime} 04^{\prime \prime} \mathrm{W}$ Longitude, while inundation reaches a maximum of $280 \mathrm{~m}$ inland between Coal Oil Point and Goleta Point. The water current reaches its maximum of $5.1 \mathrm{~m} / \mathrm{s}$ around $119^{\circ} 57^{\prime} 08^{\prime \prime} \mathrm{W}$ Longitude, and wave breaking is nonexistent.

\subsection{Summary}

Each of the modeled tsunamis follow a similar pattern, with maximum inundation occurring in the lower-lying areas next to Coal Oil and Goleta points, while the steep coastline further west restricts inundation. Maximum runup depends somewhat on the axis of landslide motion for each event. While there is wide variation between the relative amplitudes of the events, due to the differences in landslide dimensions and initial locations, the positions of peak runup and inundation remain relatively constant, occurring in roughly the same locations regardless of tsunami amplitude. This result is likely caused by strong bathymetric control on the focusing of waves along the coast, and of the formation and interactions of edge waves.

\section{Conclusions}

We, therefore, conclude that the Goleta slide is the product of multiple failure episodes and processes including tectonic oversteepening and earthquakes, sediment accumulation, and fluid flow, any one of which alone could cause its failures, but probably a combination of mechanisms resulted in the formation of this complex compound landslide. This large complex compound slide is comprised of as many as 24 different independent slide events extending 200 000 years back in time with the latest events occurring no earlier than sometime between 8000 and 10000 years ago. The modern and latest failures consist of over 25 different mudflow lobes and failure features (Fig. 11). We conclude that several mechanisms such as sediment accumulation, baselevel changes, and increased pore pressures from hydrocarbon gas and fluid flow or fresh water aquifer discharge sets the conditions for failure with a trigger mechanism being either one of the above mechanism or an earthquake or storm event.

If the Goleta Bulge were to fail as a coherent and rapidly accelerating landslide, then the displaced material could produce a tsunami that would be less than $6 \mathrm{~m}$ high along the Goleta-Santa Barbara coastline. We also calculate that potential past tsunamis could have been generated from seafloor failures along the northern flank of the Santa Barbara Basin that may have ranged in size from $20 \mathrm{~m}$ high if the entire Goleta slide failed as one unit, which is probably not a likely scenario, to $10 \mathrm{~m}$ high if the western segment or head wall failed.

Acknowledgements. We thank D. Caress for his assistance in processing the MBARI multibeam bathymetry data. The crews of the "Point Lobos" and "Western Flyer", pilots of the ROVs "Ventana" and "Tiburon" were extremely helpful in assisting us in the collection of in situ data. The USGS kindly provided seismic reflection profile data that were useful in determine dates of the Goleta slide. We thank an anonymous reviewer for thoughtful comments that considerably improved the manuscript. P. Watts is grateful for the assistance of J. Nathan. This work was supported by the David and Lucile Packard Foundation. We wish to thank all for their assistance. We are especially appreciative of H. Lee's review as his comments substantially improved upon the manuscript.

Edited by: S. Tinti

Reviewed by: One referee

\section{References}

Allen, A. A., Schlueter, R. S., and Mikolaj, P. G.: Natural oil seepage at Coal Oil Point, Santa Barbara, California, Science, 170, 974-976, 1970.

Bancroft, H. H.: The History of California, The History Company, San Francisco, 1, 146, 1888

Beyer, W. H. (Ed): Handbook of Mathematical Sciences, 6th ed. CRC Press, Boca Raton, Florida, 860, 1987.

Borrero, J. C., Dolan, J. F. and Synolakis, C. E: Tsunamis within the eastern Santa Barbara Channel, Geophys. Res. Lett., 28, 4, 643-646, 2001.

Bortugno, E. J.: Santa Ynez fault (south branch), Calif. Div. Mines and Geol. Fault Evaluation Rep., FER-12, 9, 1977.

Brodsky, E. E., Gordeev, E., and Kanamori, H.: Landslide basal friction as measured by seismic waves, Geophys. Res. Lett., 30(24), 2236-2240, 2003. 
Burdick, D. J. and Richmond, W. C.: A summary of Geologic Hazards for Proposed OCS Oil and Gas Lease Sale 68, Southern California, U.S. Geological Survey Open-File Report 82-33, 38, 1982.

Chen, Q., Kirby, J. T., Dalrymple, R. A., Kennedy, A. B., and Chawla, A.: Boussinesq modeling of wave transformation, breaking, and runup, II: 2D, J. Waterways, Ports, Coast, and Ocean Engineering, ASCE, 126,1, 48-56, 2000.

Crissman, S. C. and Ploessel, M. R.: Seismic evidence of mass movement in the Santa Barbara Basin, offshore southern California (Abstract), Geol. Soc. Amer. Annual Meeting, Abstracts with Program, 11(7), 407, 1979.

Crouch, J. K.: Neogene tectonic evolution of the California Continental Borderland and western Transverse Ranges, Geol. Soc. Amer. Bull., 90(4), 1338-1345, 1979.

Crouch, J. K. and Suppe, J.: Late Cenozoic tectonic evolution of the Los Angeles basin and inner California borderland: A model for core complex-like crustal extension, Geol. Soc. Amer. Bull., 105(11), 1415-1434, 1993.

Crowell, J. C.: Origin of late Cenozoic basins in southern California, in: Tectonics and sedimentation, edited by: Dickinson, W. R., Soc. Econ. Paleon. and Mineralogists Special Publication, 22, 190-294, 1974.

Davies, H. L., Davies, J. M., Perembo, R. C. B., and Lus, W. Y.: The Atiape 1998 tsunami: reconstructing the event from interviews and field mapping, Pure and Applied Geophy., 160(1011), 1895-1922, 2003.

Dibblee, T. W.: Regional geology of the Transverse Ranges Province of southern California, in: Geology and Mineral Wealth of the California Transverse Ranges, edited by: Fife, D. L. and Minch, J. A., Annual Symposium and Guidebook 10, South Coast Geol. Soc., Santa Ana, 7-26, 1982a.

Dibblee, T. W.: Geology of the Santa Ynez-Topatopa Mountains, southern California, in: Geology and Mineral Wealth of the California Transverse Ranges, edited by: Fife, D. L. and Minch, J. A., Annual Symposium and Guidebook 10, South Coast Geol. Soc., Santa Ana, 41-56, 1982b.

Dickinson, W. R., Armin, R. A., Beckvar, N., Goodlin, T. C., Janecke, S. U., Mark, R. A., Norris, R. D., Radel, G., and Wortman, A. A.: Geohistory analysis of rates of sediment accumulation and subsidence for selected California basins, in: Cenozoic Basin Development of Coastal California, edited by: Ingersoll, R. V. and Ernst, W. G., Prentice Hall, Englewood Cliffs, NJ, 123, 1987.

Dolan, J. F. and Rockwell, T. K.: Paleoseismologic evidence for a very large $\left(M_{w}>7\right)$, post-A.D. 1660 surface rupture on the Eastern San Cayetano fault, Ventura County, California: was this the elusive source of the damaging 21 December 1812 earthquake?, Bull. Seism. Soc. Amer., 91, 1417-1432, 2001.

Drake, D. E.: Suspended sediment and thermal stratification in the Santa Barbara Channel, California, Deep Sea Res., 18, 763-769, 1971.

Ducan, J. R., Hoover, R. A., Pflum, C. A., Widmier, J. M., and Daetwyler, C. C.: Near- surface geology of the Santa Ynez Unit, Santa Barbara Channel, California, Esso Production Research Company Report, 85, 1971.

Edwards, B. D. and Gorseline, D. S.: New evidence of current winnowing on Hueneme Sill, California continental borderland (Abstract), Bull. Amer. Assoc. Petrol. Geol., 62, 511, 1978.

Edwards, B. D., Lee, H. J., Crane, R. P., and Field, M. E.: Retrogressive sediment failure on a $4^{\circ}$ slope, Santa Barbara Channel, California (Abstract), Geol. Soc. America Abstracts with Pro- gram, 14(7), 481, 1982.

Edwards, B. D., Lee, H. J., and Field, M. E.: Seismically induced mudflow in Santa Barbara Basin, California continental borderland, J. Sed. Res. A65, 57-68, 1993.

Edwards, B. D., Lee, H. J., and Field, M. E.: Mudflow generated by retrogressive slope failure, Santa Barbara Basin, California continental borderland, J. Sed. Res., A65, 57-68, 1995.

Eichhubl, P. and Boles, J. R.: Scale and dynamics of fracturedrelated fluid flow in the Miocene Monterey Formation, coastal California, in: Proceedings, Geofluids II, edited by: Hendry, J., Carey, P., Parnell, J., Ruffell, A., and Worden, R., Queen's University, Belfast, 81-84, 1997.

Eichhubl, P. and Behl, R.: Field guide to 'Diagenesis, deformation, and fluid flow in the Miocene Monterey Formation': VenturaSanta Barbara-Jalama Beach-Grefco Quarry/Lompoc, in: Diagenesis, deformation, and fluid flow in the Miocene Monterey Formation of Coastal California, edited by: Eichhubl, P., Soc. Econ. Paleon. and Mineralogists, Pacific Section Special Publication, 83, 85-98, 1998.

Eichhubl, P. and Boles, J. R.: Focused fluid flow along faults in the Monterey Formation, coastal California, Geol. Soc. Amer. Bull., 112, 1667-1679, 2000a.

Eichhubl, P. and Boles, J. R.: Rates and fluid flow in fault systems - evidence for episodic fluid flow in the Miocene Monterey Formation, costal California, Amer. J. Sci., 300, 571-600, 2000 b.

Eichhubl, P., Greene, H. G., Naehr, T., and Maher, N.: Structural control of fluid flow: offshore seepage in the Santa Barbara Basin, California, J. Geochem. Explor., 69-70, 545-549, 2000.

Eichhubl, P., Greene, H. G., and Maher, N.: Physiography of an active transpressive margin basin: high-resolution bathymetry of the Santa Barbara basin, Southern California continental borderland, Marine Geology, 184, 95-120, 2002.

Enet, F., Grilli, S. T., and Watts, P.: Laboratory experiments for tsunamis generated by underwater landslides: Comparison with numerical modeling, Proc. of the 13th Offshore and Polar Eng. Conf., ISOPE03, Honolulu, Hawaii, 3, 372-379, 2003

Engelhardt, F. Z.: The Franciscans in California, The Holy Childhood Indian School, Harbor Spring, Michigan, 1897.

Feigl, K. L., Agnew, D. C., Bock, Y., Dong, D., Donnellan, A., Hager, B. H., Herring, T. A., Jackson, D. D., Jordan, T. H., King, R. W., Larsen, S., Larson, K. M., Murray, M. H., Shen, Z., and Webb, F. H.: Space geodetic measurement of crustal deformation in central and southern California, 1984-1992, J. Geophys. Res., 98, 21 677-21 712, 1993.

Field, M. E. and Edwards, B. D.: Slopes of the southern California continental borderland: A regime of mass transport, in: Quaternary Depositional Environments of the Pacific Coast, edited by: Field, M. E., Douglas, R. G., Bouma, A. H., Ingle, J. C., and Colburn, I. P., Pacific Section Soc. Econo. Paleo. and Mineralogists., Los Angeles, CA, 169-184, 1980.

Field, M. E., Gardner, J. V., and Prior, D. B.: Geometry and significance of stacked gullies on the northern California slope, Marine Geology, 154, 271-286, 1999.

Fischer, P. J.: Structure and tectonics of the northwestern Santa Barbara Basin, in: Structure and Petroleum Geology, Santa Barbara Channel, California, edited by: Kunitomi, D. S., Hopps, T. E., and Galloway, J. M., Amer. Assoc. Petrol. Geol., Pacific Section and Coast Geol. Soc., Misc. Publ., 46, Bakersfield, CA., 79-96, 1998.

Fischer, P. J. and Stevenson, A. J.: Natural hydrocarbon seeps along the northern shelf of the Santa Barbara Basin, California, in: Santa Barbara Channel Region Revisited, edited by: Kolpack, 
R. L. and Straughan, D., Amer. Assoc. Petrol. Geol. AAPG Trip 3, Los Angeles, pp. 17-28, 1973.

Fischer, P. J. and Cherven, V. B.: The Conception Fan, Santa Barbara Basin, California, in: Structure and Petroleum Geology, Santa Barbara Channel, California, edited by: Kunitomi, D. S., Hopps, T. E., and Galloway, J. M., Amer. Assoc. Petroleum Geologists, Pacific Section, Misc. Publication, 46, 155-182, 1998.

Fisher, M. A., Normark, W. R., Greene, H. G., Lee, H. J. and Sliter, R. W.: Geology and tsunamigenic potential of submarine landslides in Santa Barbara Channel, southern California, Marine Geology, 1-4, 1-22, doi:10.10161/j.margeo.2005.07.012, 2005a.

Fisher, M. A., Greene, H. G., Normark, W. R., and Sliter, R. W.: Neotectonics of the offshore Oak Ridge Fault near Ventura, southern California, Bull. Seismological Soc. Amer., 95(2), 739744, $2005 b$.

Fleisher, P.: Mineralogy and sedimentation history, Santa Barbara Basin, California, J. Sed. Petrol., 42, 49-58, 1972.

Goldfinger, C., Kulm, L. D., McNeill, L. C., and Watts, P.: Superscale failure of the southern Oregon Cascadia Margin, Pure and Applied Geophys., 157, 1189-1226, 2000.

Greene, H. G.: Late Cenozoic geology of the Ventura Basin, California, in: Aspects of the Geology History of the California Continental Borderland, edited by: Howell, D. G., Amer. Assoc. Petrol. Geol., Pacific Section Misc. Publ., 24, 499-529, 1976.

Greene, H. G., Wolf, S. C., and Blom, K. G.: The marine geology of the eastern Santa Barbara Channel with particular emphasis on the ground water basins offshore from the Oxnard Plain, southern California, U.S. Geological Survey Open-File Rept. 78-305, 104, 1978.

Greene, H. G. and Ward, S. N.: Mass movement features along the central California margin and their modeled consequences for tsunami generation, in: Submarine Mass Movements and Their Consequences, edited by: Locat, J. and Mienert, J., Kluwer Academic Publishers, The Netherlands, 343-356, 2003.

Greene, H. G., Murai, L, Ward, S., and Paull, C.: Mechanism and dating of submarine landslides along the California continental margin and their tsunami generating potential (abstract): 32nd International Geological Congress, Florence, Italy, Abs. Vol., pt. 1, abs. 115-8, 534, 2004.

Grilli, S. T. and Watts, P.; Modeling of waves generated by a moving submerged body: Applications to underwater landslides, Eng. Analysis with Boundary Elements, 2(8), 645-656, 1999.

Grilli, S. T. and Watts, P.: Modeling of tsunami generation by an underwater landslide in a 3D numerical wave tank, Proc. of the 11th Offshore and Polar Eng. Conf., Stavanger, Norway, 3, 132139, 2001.

Grilli, S. T., Vogelmann, S., and Watts, P.: Development of a 3D numerical wave tank for modeling tsunamis generation by underwater landslides, Eng. Analysis with Boundary Elements, 26(4), 301-313, 2002.

Hampton, M. A. and Bouma, A. H.: Slope instability near the shelf break, western Gulf of Alaska, Marine Geotechnology, 2, 309331, 1977.

Hampton, M. A., Lemke, R. W., and Coulter, H. W.: Submarine landslides that had a significant impact on man and his activities: Seward and Valdez, Alaska, in: Submarine Landslides: Selected Studies in the U.S. Economic Zone, edited by: Schwab, W. C., Lee, H. J., and Twichell, D. C., U.S. Geological Survey Bull., 2002, 123-134, 1993.

Hampton, M. A., Lee, H. J., and Locat, J.: Submarine landslides, Rev. Geophys., 34, 33-59, 1996.

Howell, D. G. (Ed.): Aspects of the Geology History of the Califor- nia Continental Borderland, Amer. Assoc. Petrol. Geol., Pacific Section Misc. Publ., 24, 561, 1976.

IAEG Commission on Landslides: Suggested nomenclature for landslides, Bull. Int. Assoc. of Eng. Geology, 41, 13-16, 1976.

Imran, J., Parker, G., Locat, J., and Lee, H.: 1D numerical model of muddy subaqueous and subaerial debris flow, J. Hyd. Eng., ASCE, 127(11), 959-968, 2001.

Ishihara, K. and Yoshimine, M.: Evaluation of settlements in sand deposit following liquefaction during earthquakes, Soils and Foundations, 32(1), 173-188, 1992.

Issac, C. M.: Porosity reduction during diagenesis of the Monterey Formation, Santa Barbara coastal area, in: The Monterey Formation and Related siliceous Rocks of California, Soc. Econom. Paleon. and Mineralogists, 257-271, 1981.

Iverson, R. M. and Denlinger, R. P.: Flow of variably fluidized granular masses across three-dimensional terrain: 1. Coulomb mixture theory, J. Geophys. Res., 106(B1), 537-552, 2001.

Jackson, J. and Molnar, P.: Active faulting and block rotation in the western Transverse Ranges, California1, J. Geophys. Res. 95(13), 22 073-22 087, 1990.

Jennings, C. W.: Fault Activity Map of California and Adjacent Areas with Location and Ages of Recent Volcanic Eruptions, California Geologic Data Map Series, Map No. 6, Calif. Div. Mines and Geology, 1994.

Joan, M. B., Buck, K. R., Farmer, M. A., and Bowser, S. S.: The Santa Barbara Basin is a symbiosis oasis, Nature, 403, 77-79, 2000.

Kamerling, M. J. and Luyendyk, B. P.: Tectonic rotation of the Santa Monica Mountains region, western Transverse Ranges, California, suggested by paleomagnetic vectors, Geol. Soc. Amer. Bull., 90(4), 331-337, 1979.

Kamerling, M. J. and Luyendyk, B. P.: Paleomagnetism and Neogene tectonics of the northern Channel Islands, California, J. Geophys. Res., 90(B14), 12 485-12 502, 1985.

Keller, M. A.: Ventura Basin Province (013), Geologic report on national oil and gas assessment, U.S. Geological Survey, unpublished, 1-13, 1995.

Keller, M. A. and Gurrola, L. D.: Final Report, July 2000, Earthquake Hazard of the Santa Barbara Fold Belt, California, NEHERP Award HQGR0081, Institute of Crustal Studies, Univ. of Calif., Santa Barbara, California, 77, 2000.

Kennedy, M. P., Greene, H. G., and Clarke Jr., S. H.: Geology of the California Continental Margin: Explanation of the California Continental Margin Geologic Map Series - Interpretive Methods, Symbology, Stratigraphic Units, and Bibliography, Calif. Div. Mines and Geology Bull., 207, 110, 1987.

Kennedy, A. B., Chen, Q., Kirby, J. T., and Dalrymple, R. A.: Boussinesq modeling of wave transformation, breaking, and runup. I: 1D, J. Waterways, Port, Coast, and Ocean. Eng., ASCE, 126(1), 39-47, 2000.

Kennett, J., Cannarito, K. G., Hendy, I. L., and Behl, R. J.: Carbon isotopic evidence for methane hydrate instability during Quaternary interstadials, Science, 288, 128-218, 2000.

Kolpack, R. L.: Biological and Oceanographical Survey of the Santa Barbara Oil Spill, III, Physical, Chemical and Geological Studies, Allan Hancock Foundation, Univ. of Southern California, Los Angeles, 477, 1971.

Lajoie, K. R., Ponti, D. J., Powell II, C. L., Mathieson, S. A., and Sarna-Wojcicki, A. M.: Emergent marine strandlines and associated sediments, coastal California; A record of Quaternary processes, in: Quaternary Nonglacial Geology; Conterminous U.S, edited by: Morrison, R. B., The Geology of North America K- 2, 
Geol. Soc. Amer., Boulder, CO, 190-213, 1991.

Larsen, S. C., Agnew, D. C., and Hager, B. H.: Strain accumulation in the Santa Barbara Channel: 1970-1988, J. Geophys. Res., 98, 2119-2133, 1993.

Lee, H. J. and Edwards, B. D.: Regional method of assessing offshore slope stability, J. Geotechnical Engineering, 112, 489-509, 1986.

Lee, H. J., Schwab, W. C., Edwards, B. D., and Kayen, R. E.: Quantitative controls on submarine slope failure morphology. Marine Geotechnology, 10(1/2), 143-158, 1992.

Lee, H. J., Schwab, W. C., and Booth, J. S.: Submarine landslides: An Introduction, in: Submarine Landslides: Selected Studies in the U.S. Exclusive Economic Zone, edited by: Schwab, W. C., Lee, H. J., and Twichell, D. C., U.S. Geological Survey Bull. 2002, 1-13, 1993.

Lee, H. J., Kayen, R. E., Gardner, J. V., and Locat, J.: Characteristics of several tsunamigenic submarine landslides, in: Submarine Mass Movements and their consequences, edited by: Locat, J. and Mienert, J., Kluwer Academic Publishers, The Netherlands, 357-366, 2003.

Lee, H. J., Normark, W. R., Fisher, M. A., Greene, H. G., Edwards, B. D., and Locat, J.: Timing and extent of submarine landslides in southern California, Offshore Tech. Conf., OTC Paper Number 15744, 2004.

Luyendyk, B. P.: Structure under the Santa Barbara Channel: The thick and thin of it, in: Structure and Petroleum Geology, Santa Barbara Channel, California, edited by: Kunitomi, D. S., Hopps, T. E. and Galloway, J. M., Amer. Assoc. Petroleum Geologists, Pacific Section Misc. Publ., 46, 79-96, 1998.

Lynett, P., and Liu, P. L.-F., A numerical study of submarine landslide generated waves and runup, PROSOC, 458, 2885-2910, 2002.

MBARI Seafloor Mapping Team: Santa Barbara multibeam survey, Monterey Bay Aquarium Research Institute Digital Data Series 4, Moss Landing, CA, 2 CD- ROMS, 2001.

McCulloch, D. S.: Geologic Map of the South-Central California Continental Margin - Map No. 4A (Geology), Sheet 1 of 4, in: California, Continental Margin Geologic Map Series SouthCentral California Continental Margin Area 4 of 7, edited by: Greene, H. G. and Kennedy, M. P., Calif. Div. Mines and Geol., scale 1:250 000, 1989.

Moore, J. G., Clague, D. A., Holcomb, R. T., Lipman, P. W., Normark, W. R., and Torresan, M. E.: Prodigious submarine landslides on the Hawaiian Ridge, J. Geophy. Res., 94, 17465 $17484,1989$.

Moore, J. G., Normark, W. R., and Holcomb, R. T.: Giant Hawaiian landslide, Annual Rev. Earth and Planet, Science, 22, 119-144, 1994.

Namson, J. and Davis, T.: Structural transect of the western Transverse Ranges, California: Implications for lithospheric kinematics and seismic risk evaluation, Geology, 16, 675-679, 1988.

Nicholson, C. Sorlien, C. C., Atwater, T., Crowell, J. C., and Luyendyk, B. P.: Microplate capture, rotation of the western Transverse Ranges, and initiation of the San Andreas transform as a low-angle fault system, Geol. Soc. Amer. Bull., 22, 491-495, 1994.

Pirie, D. M. and Steller, D. B.: California Coastal Processes LANDSAT II, Final Report, NASA Goddard Space Flight Center, Greenbelt, Maryland, 146, 1977.

Pinter, N. and Sorlien, C. C.: Evidence for latest Pleistocene to Holocene movement on the Santa Cruz Island fault, California, Geology, 19, 909-912, 1991.
Plafker, G., Kachadoorian, R., Eckel, E. B., and Mayo, L. R.: Effects of the earthquake of 27 March 1964, on various communities, U.S. Geological Survey Professional Paper, 542-G, 50, 1969.

Ploessel, M. R., Crissman, S. C., Rudat, J. H, Son, R., Lee, R. F., Randall, G. R., and Norton, M. P.: Summary of potential hazards and engineering constraints, proposed OCS lease sale no. 48, offshore southern California, Proc. 11th Ann. Offshore Tech. Conf., Houston, Texas, 1979.

Prior, D. B. and Coleman, J. M.: Disintegrating retrogressive landslides on very-low-angle subaqueous slopes, Mississippi Delta, Marine Geotech., 3, 37-60, 1978.

Prior, D. B., Wiseman, W. J., and Gilbert, R.: Submarine slope processes on a fan delta, Howe Sound, British Columbia. GeoMar. Lett., 1, 85-90, 1981.

Prior, D. B., Bornhold, B. D., Coleman, J. M., and Bryant, W. R.: Morphology of a submarine slide, Kitimat Arm, British Columbia, Geology, 10, 588-592, 1982.

Quigley, D. C., Hornafius, J. S., Luyendyk, B. R., Francis, R. D., Clark, J., and Washburn, L.: Decrease in natural marine hydrocarbon seepage near coal Oil Point California, associated with offshore oil production, Geology, 27, 1047-1050, 1999.

Richmond, W. C., Cummings, L. J., Hamlin, S., and Nagarty, M. E.: Geologic hazards and constraints in the area of OCS oil and gas sale 48, southern California, U.S. Geological Survey Open-File Rept., 81-307, 33, 1981.

Rockwell, T. K., Keller, E. A., and Dembroff, G. A.: Quaternary rate of folding of the Ventura anticline, western Transverse Ranges, southern California, Geol. Soc. Amer. Bull., 100, 850 858, 1988.

Savage, S. B., and Hutter, K.: The motion of a finite mass of granular material down a rough incline, J. Fluid Mech., 199, 177-215, 1989.

Schwab, W. C., Lee, H. J., and Twichell, D. C.: Submarine landslides: selected studies in the U.S. Exclusive Economic Zone, U.S. Geological Survey Bull., 2002, 204, 1993.

Senan, F. J., and Vitoria, F. M. A.: Baptismal Entries, Santa Barbara Mission Archives Document CMD, 943a, 1813.

Shepard, F. P.: Depth changes in Sagami Bay during the great Japanese earthquake, J. Geol., 41, 527-536, 1933.

Silver, E., Day, S., Ward, S., Hoffmann, G., Llanes, P., and Lyons, A.: Volcanic collapse and tsunami generation in Papua New Guinea - a comprehensive marine geophysical study of Ritter Island and other collapses, Amer. Geophys. Union, EOS, 86, 47, 485-489, 2005.

Sorlien, C. C., Kamerling, M. J., and Mayerson, D.: Block rotation and termination of the Hosgri strike-slip fault, California, from three-dimensional map restoration, Geology, 27, 10391043, 1999.

Sorlien, C. C., Gratier, J.-P., Luyendyk, B. P., Hornafius, J. S., and Hopps, T. E.: Map of folded and faulted late Cenozoic strata across the Oak Ridge fault, onshore and offshore Ventura basin, California, Evolution of Continental Slope Gullies on the Northern California Margin, J. Sed. Res., 71, 237-245, 2000.

Sylvester, A. G.: Aseismic growth of Ventura Anticline, southern California, 1978- 1997: Evidence from precise leveling, Surveying and Land Infor. Sci., 60, 95-108, 2000.

Synolakis, C. E., Bardet, J.-P., Borrero, J. C., Davis, H., Grilli, E. A., Okal, E. A., Silver, E. A., Sweet, S., Tappin, D. R., and Watts, P.: Slump origin of the 1998 Papua New Guinea tsunami, Proceedings of the Royal Society, London, Series A, 458, 763789, 2002. 
Tappin, D. R., Matsumoto, T., Watts, P., Satake, K., McMurty, G., Matsuyama, M., Lafoy, Y, Tsuji, Y., Kanamatsu, T., Lus, W., Iwabuchi, Y., Yea, H., Matsumotu, M., Mahoi, M., Hill, P., Crook, K., Anton, L., and Walsh, J. P.: Sediment slump likely caused 1998 Papua New Guinea Tsunami, EOS Transactions of the American Geophysical Union, 80, 329, 334, 340, 1999.

Tappin, D. R., Watts, P., McMurty, G. M., Lafoy, Y., and Matsumoto, T.: The Sissano, Papua New Guinea tsunami of July, 1998 - offshore evidence on the source mechanism, Marine Geology, 175, 1-23, 2001.

Thornton, S. E.: Suspended sediment transport in surface waters of the California Current off southern California: 1977-1978 floods Geo-Mar. Lett. 1, 23-28, 1981

Thornton, S. E.: Basin model for hemipelagic sedimentation in a tectonically active continental margin: Santa Barbara Basin, California Continental Borderland, in: Fine-Grained Sediments: Deep Water Processes and Facies, edited by: Stow, D. A. V., and Piper, D. J. W., Geol. Soc. of London Spec. Publ., 15, 377-394, 1984.

Thornton, S. E.: Origin of mass flow sedimentary structures in hemipelagic basin deposits: Santa Barbara Basin, California borderland, Geo-Mar. Lett., 6, 15-19, 1986.

Thornton, S. E. and Crissman, S.: Spatial distribution of mass movement in Santa Barbara Basin: sedimentologic evidence (abstract), Geol. Soc. Amer. Ann. Meeting, Abstracts with Program, 11(7), 527-528, 1979.

Toppozada, T. R., Real, C. R., and Parke, D. L.: Preparation of isoseismal maps and summaries of reported effects for pre-1900 California earthquakes, Calif. Div. Mines and Geol. Open-File Report, 81-11, 172-174, 1981.

Toppozada, T. R., Branum, D. M., Petersen, M., Hallstrom, C., Cramer, C., and Reichle, M.: Epicenters of and areas damaged by $M \geq 5.5$ California earthquakes, 1800-1999, Calif. Div. Mines and Geol. Map Sheet 49, scale 1:1 562 500, 2000.

Toppozada, T. R., Branum, D. M., Reichle, M. S., and Hallstrom, C. L.: San Andreas fault zone, California, $\geq 5.5$ earthquake history, Bull. Seismo. Soc. Amer., 92(7), 2555-2601, 2002.

Townley, M. D. and Allen, M. W.: Descriptive catalog of earthquakes of the Pacific coast of the United States, 1769-1982, Bull. Seism. Soc. Amer., 29, 1-297, 1939.

Trask, J. B.: Earthquakes in California from 1812 to 1855 , The Golden Era, San Francisco, 1, 1856

Trask, J. B.: Earthquakes in California from 1800 to 1864, Proc. Calif. Academy Sci., 1st Series, 3, 130-151, 1864.

United States Geological Survey: Draft environmental statement on oil and gas development in the Santa Barbara Channel, outer continental shelf, off California, Final Environmental Statement, 75-35, 3 volumes, 1975.

Varnes, D. J.: Slope movement types and processes, in: Special Report 176: Landslides: analysis and control, edited by: Schuster, R. L. and Krizek, R. J., TRB, National Research Council, Washington, D.C., 11-33, 1978.

Vedder, J. G., Greene, H. G., Clarke, S. H., and Kennedy, M. P.: Geologic map of the mid-central California continental margin, in: California Continental Margin Geologic Map Series, edited by: Greene, H. G. and Kennedy, M. P., Calif. Div. of Mines and Geol., 2A (Geology), 1:250 000, 1986.

Vedder, J. G., Greene, H. G., Clarke, S. H., and Kennedy, M. P.: Geologic map of the south-central California continental margin, in: California Continental Margin Geologic Map Series, edited by: Greene, H. G. and Kennedy, M. P., Calif. Div. of Mines and Geol., 4A (Geology), 1:250 000, 1989.
Vernon, J. W., and Slater, R. A.: Submarine tar mounds, Santa Barbara County, California, Bull. Amer. Assoc. Petrol. Geol., 47, 1624-1627, 1963.

Walder, J. S., Watts, P., Sorensen, O. E. and Janssen, K.: Water waves generated by subaerial mass flows, J. Geophys. Res. 108(B5), 2236-2255, 2003.

Ward, S. N.: Landslide tsunami, J. Geophys. Res., 106(B6), 11201 $11216,2001$.

Watts, P.: Water waves generated by underwater landslides, Ph.D. thesis, Div. of Engrg. and Applied Sci., California Institute of Technology, Pasadena, California, 1997.

Watts, P.: Wavemaker curves for tsunamis generated by underwater landslides, J. Waterways, Port, Coast, and Ocean. Eng., ASCE, 124(3), 127-137, 1998.

Watts, P.: Tsunami features of solid block underwater landslides, J. Waterways, Port, Coast, and Ocean. Eng., ASCE, 126(3), 144$152,2000$.

Watts, P., Imamura, F., and Grilli, S. T.: Comparing model simulations of three benchmark tsunami generation cases, Sci. Tsunami Hazards, 18(2), 107-124, 2000.

Watts, P. and Grilli, S. T.: Underwater landslide shape, motion, deformation, and tsunami generation, Proc. of the 13th Offshore and Polar Eng. Conf., ISOPE03, Honolulu, Hawaii, 3, 364-371, 2003.

Watts, P., Grilli, S. T., Kirby, J. T., Fryer, G. J., and Tappin, D. R.: Landslide tsunami case studies using a Boussinesq model and a fully nonlinear tsunami generation model, Nat. Hazards and Earth Sci. Syst., 3, 391-402, 2003.

Watts, P.: Probabilistic analyses of landslide tsunami hazards, in: Submarine Mass Movements and Their Consequences, edited by: Locat, J. and Mienert, J., Kluwer Academic Publishers, The Netherlands, 163-170, 2004a.

Watts, P.: Deposition in a hazard assessment model of mass transport complexes, Offshore Tech. Conf., OTC Paper No. 1646, Houston, TX, 3, 2004b.

Watts, P.: Probabilistic predictions of landslide tsunamis off southern California, Marine Geology, 203, 281-301, 2004c.

Watts, P. and Waythomas, C. F.: Theoretical analysis of tsunami generation by pyroclastic flows, J. Geophys. Res., 108(B12), 2563-2584, 2004.

Wei, G. and Kirby, J. T.: Time-dependent numerical code for extended Boussiniesq equations, J. Waterways, Port, Coast, and Ocean. Eng., ASCE, 121, 5, 251-261, 1995.

Wei, G., Kirby, J. T., Grilli, S. T., and Subramanya, R.: A fully nonlinear Boussinesq model for free surface waves, Part 1: Highly nonlinear unsteady waves, J. Fluid Mech., 294, 71-92, 1995.

Wilkinson, E. R.: California offshore oil and gas seeps, California Summary of Operations, Calif. Depart. of Conservation, Div. of Oil and Gas, 57, 5-28, 1972.

Wilson, B. W. and Torum, A.: Effects of the tsunamis: an engineering study, in: The Great Alaska earthquake of 1964, National Academy of Sciences, Washington, D.C., 361-523, 1972.

Yeats, R. S.: Quaternary flake tectonics of the California Transverse Ranges, Geology, 9, 16-20, 1981.

Yeats, R. S.: Large-scale Quaternary detachments in Ventura Basin, southern California, J. Geophys. Res., 88, 569-583, 1983.

Yerkes, R. F., Greene, H. G., Tinsley, J. C., and Lajoie, K. R.: Seismotectonic setting of the Santa Barbara Channel Area, southern California, U.S. Geological Survey Misc. Field Studies Map MF1169, 25, 1981. 